\title{
A political ecology of transdisciplinary research
}

\author{
Hali Healy ${ }^{1}$ \\ University of Johannesburg, South Africa
}

\begin{abstract}
Transdisciplinary research (TDR) is widely regarded as a promising, and even essential, means of addressing complex sustainability problems, whilst delivering beneficial outcomes for scientists and the non-academic actors with whom they engage. Premised on the 'ecological modernisation' of Europe, regional funding for TDR under Framework Programmes such as FP7 and more recently Horizon 2020 have sought to support academic engagement with a wide range of research stakeholders through calls for transdisciplinary research in order to better address Europe's "grand societal challenges" (EC 2013). This article, based on doctoral research, consists of an ex-post study of three European Union funded transdisciplinary projects (CREPE, EJOLT and GAP2) implemented under the Seventh Framework's (2007-2013) Science in Society program. Its focus is on how issues of power and governance permeate TDR projects, giving rise to tensions, challenges and ultimately struggles over the very meaning of official projects and their outcomes, despite the most egalitarian of intentions and underlying principles of mutual benefit. These tensions, this article argues, should be understood not merely as cultural, methodological or cognitive challenges, but as essentially political conflicts that manifest and flow across multiple scales. In light of these inherent challenges, the article argues that TDR is always conducted on a terrain of political ecology, and concludes by making recommendations for potential collaborators, as well as for European research policy makers, with the objective of enabling participants and funders alike to realise the transformative potential of this promising mode of research.
\end{abstract}

Keywords: Political ecology of transdisciplinary research, power, governance, Science in Society, European research agenda, agro-ecology, environmental justice, fisheries

\section{Résumé}

La recherche transdisciplinaire (TDR) est largement considérée comme un moyen prometteur, voire essentiel, de traiter des problèmes complexes de durabilité, tout en produisant des résultats bénéfiques pour les scientifiques et les acteurs non universitaires avec lesquels ils s'engagent. Sur la base de la "modernisation écologique" de l'Europe, le financement régional du TDR au titre de programmes-cadres tels que le FP7 et, plus récemment, Horizon 2020 ont cherché à soutenir l'engagement des universitaires avec un large éventail de parties prenantes de la recherche par le biais d'appels à une recherche transdisciplinaire afin de mieux traiter l'Europe "grands défis de société ». Cet article, basé sur une recherche doctorale, consiste en une étude ex post de trois projets transdisciplinaires financés par l'Union européenne, l'un axé sur l'écologie politique (CREPE, EJOLT et GAP2) et mis en œuvre dans le cadre du programme Science dans la Société FP7 (2007-2013). Il se concentre sur la manière dont les questions de pouvoir et de gouvernance imprègnent les projets TDR, générant tensions, défis et luttant finalement sur le sens même des projets officiels et de leurs résultats, malgré les intentions les plus égalitaires et les principes sous-jacents de bénéfice mutuel. Cet article soutient que ces tensions doivent être comprises non seulement comme des défis culturels, méthodologiques ou cognitifs, mais également comme des conflits essentiellement politiques qui se manifestent et se déroulent à plusieurs niveaux. Compte tenu de ces défis inhérents, l'article conclut en faisant des recommandations aux éventuels collaborateurs du TDR, ainsi qu'aux décideurs politiques européens dans le domaine de la recherche, dans le but de permettre aux participants et aux bailleurs de fonds de réaliser le potentiel de transformation de ce mode de recherche prometteur.

Mots-clés: L'écologie politique de recherche transdisciplinaire, pouvoir, gouvernance, Science dans la Société, agenda de recherche européen, agro-écologie, justice environnementale, pêche

\footnotetext{
${ }^{1}$ Dr. Hali Healy, Lecturer, Department of Anthropology and Development Studies, University of Johannesburg, South Africa. Email: hhealy "at" uj.ac.za. The author wishes to acknowledge and thank the referees of this article, the coordinators of CREPE (Les Levidow), EJOLT (Joan Martinez-Alier) and GAP2 (Steve Mackinson) for their support for this research, and the interviewees who gave so willingly of their time in interviews and comments on drafts.
} 


\section{Resumen}

La investigación transdisciplinaria (ITD) se suele considerar como un método prometedor e incluso esencial para abordar problemas complejos de sostenibilidad, al tiempo que ofrece resultados beneficiosos para los científicos y los actores no académicos que se involucran. Con la premisa de la 'modernización ecológica' de Europa, la financiación para la ITD en virtud de los Programas Marco, como el 7PM y, más recientemente, Horizon 2020 han tratado de apoyar la participación académica con una amplia gama de otros interesados en la investigación a través de convocatorias de investigación transdisciplinaria para abordar mejor los "grandes desafíos sociales" que confrontan a Europa (CE 2013). Este artículo, basado en una tesis doctoral, consiste en un estudio ex post de tres proyectos transdisciplinarios financiados por la Unión Europea (CREPE, EJOLT y GAP2) implementados bajo el programa Science in Society (la Ciencias en la Sociedad) del Séptimo Programa Marco (2007-2013). Se centra en cómo las cuestiones de poder y gobernanza impregnan los proyectos de ITD, dando lugar a tensiones, desafíos y, en última instancia, luchas sobre el significado mismo de los proyectos oficiales y sus resultados, a pesar de las intenciones igualitarias y los principios subyacentes de beneficio mutuo. Estas tensiones, argumenta este artículo, deben entenderse no solo como desafíos culturales, metodológicos o cognitivos, sino como conflictos esencialmente políticos que se manifiestan y fluyen a través de múltiples escalas. A la luz de estos desafíos inherentes, el artículo argumenta que la ITD siempre se lleva a cabo en un terreno de ecología política, y concluye haciendo recomendaciones para posibles colaboradores, así como para los responsables políticos europeos de la investigación, con el objetivo de permitir por igual a los participantes y financiadores de realizar el potencial transformador de este prometedor modo de investigación. Palabras clave: ecología política de la investigación transdisciplinaria, poder, gobernanza, ciencia en sociedad, agenda de investigación europea, agroecología, justicia ambiental, pesca.

\section{Introduction: Why a political ecology of TDR?}

Transdisciplinarity is defined by Lang et al. (2012: 27) as "a reflexive, integrative, method-driven scientific principle aiming at the solution or transition of societal problems and concurrently of related scientific problems by differentiating and integrating knowledge from various scientific and societal bodies of knowledge." Born in the 1970s, transdisciplinary thinking grew out of a realization of the inadequacy of the compartmentalized and highly specialized disciplinary structure of science in terms of understanding, analyzing and addressing complex social problems, notably with regard to environmental degradation (Hadorn et al. 2008).

Rather than being regarded as a well-defined theory or methodology, transdisciplinarity should be understood as an evolving approach (Görg et al. 2014; Hadorn et al. 2006; Jahn et al. 2012; Pohl 2008; Russell et al. 2008), rooted in an appreciation of a need for "post normal science" (PNS), which calls for the meaningful involvement of an extended peer community "when facts are uncertain, values in dispute, stakes high and decisions urgent" (Funtowicz and Ravetz 1991, 1993, 2003). Also referred to as "Mode 2" knowledge, (Gibbons et al. 1994), transdisciplinary research (TDR) is inspired by systems thinking (Pohl and Hadorn 2008) and, as such, aims to "provide descriptive, normative and practice-oriented knowledge" able to grasp the complexity of problems, account for a diversity of perceived life-world and scientific dilemmas, link abstract and case-specific knowledge, and develop knowledge and practices able to advance a sort of "common good" (Pohl and Hadorn 2008: 20).

Regarded by some scholars as "the (italics added) sustainability science" (Görg et al. 2014; Hadorn et al. 2006; Spangenberg 2011), TDR continues to be viewed with increasing interest by researchers, policy makers and civil society alike. For academics, TDR promises to "bring universities and other knowledge organizations into line with new demands, opportunities and imperatives" (Russell et al. 2008: 460), notably, the imperative of producing socially relevant knowledge (Popa et al. 2015; Sugiyama et al. 2017). Nonacademic partners, notably civil society organizations (CSOs) ${ }^{2}$ meanwhile, seek out opportunities to collaborate in TDR in order to build organizational learning capacities, to produce knowledge of practical value for sustainability-related campaigning and advocacy activities (Gall et al. 2014; Greyl et al. 2012; MartinezAlier et al. 2014), or out of a desire to engage in 'upstream' forms of engagement, notably research agenda

\footnotetext{
${ }^{2}$ For the purposes of the study, CSOs are broadly defined as (primarily) non-research and non-state actors. They included non-government and community-based organizations, a fishing industry association, and several of these organizations' network members, one of which was British supermarket chain Marks and Spencer.
} 
setting (Ferretti and Pavone 2009). For policy makers, TDR offers new opportunities for knowledge production and decision-making (Lang et al. 2012), ones that democratize processes of knowledge creation via the increased engagement of wider publics in research, identifying emergent challenges and thereby producing more effective strategies and policies for governing Europe (EC 2006, 2012a). This point has not been lost on research policymakers in Europe, as calls for transdisciplinary research have proliferated in recent Framework Programmes (FPs), first under the Sixth FP (FP6), and continuing under FP7, notably via the Science in Society sub-program, and then Horizon 2020, through the Science With And For Society (SWAFS) sub-program, and the Responsible Research and Innovation (RRI) agenda and associated initiatives.

Across these realms, the theory and practice of TDR is underpinned by the notion of mutual learning, described by Russell et al. as a "consensual and equal exchange between researchers and other involved people." (2008: 468). The 2002 World Summit on Sustainable Development in Johannesburg was instrumental in embedding principles of mutual benefit and egalitarianism in TDR, where the central role of science in achieving sustainable development was recognized amid calls to "transform research by involving stakeholders and promoting mutual learning between science and the life-world" (Hadorn et al. 2008: 27). Aspirations of mutual learning and egalitarianism aside, the reality in practice, this article argues, is that the practice of TDR, at least in the context of European Commission's Framework Programme, is a political endeavor through and through. It is one in which differently empowered actors, with competing aims and interests, negotiate and sometimes struggle to ensure their objectives are met. Power dynamics permeate the landscape of TDR projects, creating tensions and challenges that can lead to struggles over the very meaning of projects. There is, therefore, a political ecology of transdisciplinary research.

\section{Methodology}

This article draws from the findings of a doctoral thesis that examined, ex-post, three transdisciplinary research projects funded under Europe's Seventh Framework Programme (FP7):

- CREPE (Co-operative Research on Environmental Problems in Europe 2008-2010)

- EJOLT (Environmental Justice Organizations, Liabilities and Trade 2011-2015)

- GAP2 (Bridging the Gap Between Science, Stakeholders, and Policy Makers 2011-2015).

All three projects set out to empower and support CSO stakeholders to participate in cooperative research, at the same time challenging dominant policy assumptions in the areas of agro-ecology, environmental degradation, and fisheries management. Motivated by my personal involvement in one of the projects (see Section 3 on EJOLT), the objective is to conduct a qualitative assessment of the outcomes of these European Framework-funded TDR projects from the perspective of project participants. I show to what extent participating academics feel TDR collaboration had improved their capacities for engaging with CSOs, whether TDR cooperation produced "actionable" knowledge or opportunities for further collaboration, and how far projects contributed to the opening of academic discourses, processes, strategies, or agendas to the participation of non-research stakeholders. For non-academic partners, typically less powerful in TDR projects, the question is how far CSO partner views and objectives were successfully integrated or balanced with those of academics throughout the research process, and how far these partners succeeded in building organizational capacity, generating tangible outcomes, and in general, achieving organizational goals. At the policy level, has any sort of institutional learning occurred, either in terms of shaping European research agendas, or funding structures/institutions themselves?

Data for the original study was primarily derived from fieldwork consisting of semi-structured interviews with over 60 project consortia members (around 20 from each project) and six research policy officers from the European Commission's Department of Research and Innovation (DG RTD). Interviews were carried out over a three to four year span, commencing mid-way through each of the projects and continuing through a 1-2 year period after their completion. Data analysis entailed an in-depth examination of "productive interactions" (Spaapen and van Drooge 2011), defined as "exchanges between researchers and stakeholders in which knowledge is produced and valued that is both scientifically robust and socially relevant" (p. 212). This 
focus on productive interactions, as it turned out, proved fruitful in unexpected ways, as CSO-academic exchanges also revealed themselves to be a locus of a wide variety of tensions, produced through the intermingling of actors with conflicting priorities, clashing expectations, and contrasting perceptions of project outcomes. Fieldwork was triangulated with a wide range of documentary evidence (including official project reports and independent project evaluation reports) as well as accounts from other project participants.

With regard to the original study, it should be noted that due to my own role in one of the projects examined (EJOLT), I deployed a critical auto-ethnographic approach, "grounded in the recognition that conditions of existence within a particular context, and for specific subjects are not what they should or could be" (Dutta 2014: 92). In line with Madison (2005: 5), my own positionality in EJOLT had ultimately inspired in me a sense of moral responsibility to become more sensitive to how cooperative processes can be seen as unfair, or unbalanced within the "lived domain" of TDR. Furthermore, it had motivated me to achieve a greater degree of research reflexivity as an academic. Focusing on the production of project "deliverables" had hindered this. A key objective is to "[disrupt] the status quo and [challenge] those institutions and regimes that limit choices, constrain resources, and marginalize identities" all the while proclaiming a commitment to "the construction of knowledge that privileges the perspectives of those who have been subjugated" (Madison 2005: 5). While this current contribution represents a highly condensed version of the original doctoral project, it aims to provide a rich and detailed snapshot of how political dynamics permeate TDR projects. At times they constrain, and even marginalize the very subjects that such endeavors intend to empower. With this objective in mind, the specific sets of interactions in this article were chosen on the basis of the accessibility of respondents, and their willingness and their ability to reflect with such lucidity, some years following project completion.

\section{The projects}

All three projects in this study fell under a rubric of sustainable development but were distinct in many ways. The subject matter of each was unique, ranging from agro-ecology and environmental justice, to fisheries management. Cooperative relations across the projects were also differently configured, each with different management arrangements, forms of partnership/collaboration, and research objectives. Yet, all three projects shared an important central aim - that of enabling non-academic stakeholders to contribute to and benefit from the production of scientific knowledge, at the same time producing socially-relevant knowledge capable of responding to major social/environmental challenges.

\section{CREPE}

The focus in CREPE (funded under SiS- 2007-1.2.1.2 - Co-operative research) was on agroenvironmental issues, with the broad objective of strengthening CSO capacity to participate in research via a learning-by-doing approach. CREPE was conceived of in a research policy context that was highly influenced by the final report of the 2005 GoverScience Workshop, which defined cooperative research as a "process which involves both researchers and non-researchers in close co-operative engagement for co-building knowledge" (EC 2006: 6-7). CREPE was also part of a novel sub-program (since discontinued) called Research for the Benefit of Specific groups - CSOs (RBSG-CSOs). This special instrument was designed to "develop scientific knowledge related to CSO activities in order to contribute to public debate, [inviting] CSOs and ROs to form partnerships and combine their knowledge" (Kuhn et al. 2014: 188).

It was in this wider research policy context, explicitly concerned with increasing CSO participation in the production of scientific knowledge, that Les Levidow, a senior researcher at the Open University in the UK conceived of CREPE. Levidow had considerable expertise in biology, technology policy, and technological innovation and regulation. He was also highly critical of the European policy imperative of developing a regional 'bioeconomy.' He gradually assembled the CREPE consortium by contacting individuals with whom he had shared interests or had worked with in various ways over the years. They developed the overall work plan, as well as the individual work projects, comprised of studies that would be led by CSO partners (Table 1). As Levidow recalled, "For the drafting of the proposal I had to take a strong role in the drafting, getting 
comments from them to make sure it evolved in time, so I'm not sure how balanced it was but they were happy with it. That's what matters" (Levidow, L. 2012, personal interview, 23 November).

In this manner the overarching objective of CREPE evolved as "empower[ing] and resource[ing] civil society organizations (CSOs) to participate in co-operative research on agro-environmental issues" (CREPE 2010a: 2). Accordingly, CREPE's objectives were implicitly political, aiming to enable citizens to challenge dominant policy assumptions based on a narrow, technocratic and highly instrumental definition of "societal challenges", as well as prescribed solutions, practices of knowledge production, and conceptions of sustainability (see Box 1; CREPE 2011: 3).

To achieve these objectives, a series of work packages were designed, conceived as studies led by different CSOs (in contrast to EJOLT and GAP2). Within each work package, collaborative processes took place on two levels. First, each work package entailed a study and complementary workshop open to participants from civil society and academia from outside the CREPE consortium, the proceedings/outputs of which would either inform or become integrated with the study. On a second level, CREPE provided crossproject "enabling spaces" (CREPE 2010c: 16) or meetings for joint CSO/academic reflection. These were embedded where possible in project-wide workshops, so that the entire CREPE team could meet to exchange experiences with regard to progress with or concerns over the cooperative elements of their work. Discussions in these spaces centered around a diary-keeping exercise that all partners were required to take part in, documenting their thoughts on and responses to cooperative research processes.

\begin{tabular}{|c|c|c|c|}
\hline Type & Acronym & $\begin{array}{l}\text { Full organization name and } \\
\text { country }\end{array}$ & CSO-led study \\
\hline Res & FNCA & $\begin{array}{l}\text { Fundación Nueva Cultura del } \\
\text { Agua, ES }\end{array}$ & \\
\hline Research & $\mathrm{OU}$ & $\begin{array}{l}\text { Open University, UK } \\
\text { (Coordinator) }\end{array}$ & \\
\hline Research & UT & University of Twente, NL & \\
\hline $\mathrm{CSO}$ & FDG & $\begin{array}{l}\text { Fondazione dei Diritti Genetici, } \\
\text { IT }\end{array}$ & $\begin{array}{l}\text { Community Supported Agriculture } \\
\text { in Italy }\end{array}$ \\
\hline $\mathrm{CSO}$ & FEC & Food Ethics Council, UK & $\begin{array}{l}\text { Water Scarcity and its Virtual } \\
\text { Export From Spain }\end{array}$ \\
\hline $\mathrm{CSO}$ & FRCIVAM & $\begin{array}{l}\text { Federation Régionale des Centres } \\
\text { d'Initiatives pour Valoriser } \\
\text { l'Agriculture, FR }\end{array}$ & $\begin{array}{l}\text { Local Agri-Food Networks and } \\
\text { Environmental Effects }\end{array}$ \\
\hline $\mathrm{CSO}$ & FSC & $\begin{array}{l}\text { Fondation Sciences Citoyennes, } \\
\text { FR }\end{array}$ & $\begin{array}{l}\text { European Research Area Priorities } \\
\text { for Sustainable Agriculture }\end{array}$ \\
\hline $\mathrm{CSO}$ & TNI & Transnational Institute, NL & $\begin{array}{l}\text { Agro-fuel Production in Europe } \\
\text { and the Global South }\end{array}$ \\
\hline
\end{tabular}

Table 1: CREPE Partners (adapted from CREPE 2010a)

Indeed the intention of DG RTD to provide dedicated support for CSO engagement in research was laudable. However it is noteworthy that just after CREPE was accepted for funding, the EC's Research Executive Agency (REA) - charged with administrative tasks such as drawing up contracts and dispersing project funds - took issue with the categorization of some CSO partners as Research Organizations (ROs), and for reasons still unknown to the project coordinator and affected participants, decided to re-categorize them as CSOs. As a result, at least two partners, including the Food Ethics Council (FEC - see below), were required to invest scarce human resources and time in resubmitting what was for them, a substantial amount of 
paperwork, in order to receive funding well after project work had already commenced. The subsequent delay in disbursement was indeed unfortunate, as well as ironic, as it threatened to undermine the research capacities of the very actors the scheme had intended to "empower."

1. Capacities: To strengthen CSO's capacity to participate in research, while engaging with diverse perspectives and expertise - thus facilitating co-operation between researchers and non-researchers, as well as between academics and CSOs.

2. Co-operative research methods: To design and test the methods used for co-operative research, as a basis to inform future efforts.

3. Agro-environmental issues: To analyze diverse accounts of 'the environment' in relation to agricultural methods, technologies, innovations and alternatives.

4. Priority-setting: To relate research more closely to societal needs, as a means to inform policy debate and research priorities for Europe as a 'Knowledge-Based Society'.

5. Solutions: To suggest alternative solutions related to different understandings of societal problems, agro-environmental issues and sustainable development.

Box 1: CREPE objectives. (Adapted from CREPE 2010a)

In spite of these bureaucratic obstacles, evidence indicates that the cooperative research processes within CREPE produced numerous positive outcomes and outputs for partners, the latter including at least ten academic and other publications designed to challenge policy assumptions and trajectories related to the pursuit of bio-economies (notably Levidow and Oreszczyn 2012). Even so, a glimpse into the FEC/FNCA work package on water scarcity produces insights into how political dynamics can still circulate within and around TDR to shape project outcomes in unexpected ways.

\section{Water scarcity and its virtual export from Spain to the UK}

This stream of CREPE revolved around cooperation led by the FEC in collaboration with Spanish research partner, the Fundación Nueva Cultura del Agua (FNCA). The FEC is a London-based NGO with expertise in working with policy, civil society and private sector actors to provide "independent advice on the ethics of food and farming" in order to "create a food system that is fair and healthy for people, animals and the environment" ${ }^{3}$. Through CREPE, the FEC planned a study that sought to analyse the contribution of food production processes to water scarcity, exploring potential ways to alleviate pressure on water supply, focusing on Almería as a case study (CREPE 2010b: 1). This plan was arguably inspired by a pre-existing relationship between the FEC and British supermarket chain Marks and Spencer (M\&S), a member and regular participant in FEC-hosted workshops, seminars and business fora. As Tom Macmillan reflected, "our interest in water stewardship...grew out of some of those business forum meetings, so our interest in getting involved in CREPE was in part informed by some of the speakers we had heard through those events" (MacMillan, T. 2013, personal interview, 29 March).

The design of the FEC study evolved in a somewhat fragmented manner. FEC Director Tom MacMillan was the main author at the proposal stage, working with Les Levidow, the project coordinator, to align the FEC's goals with the wider objectives of CREPE. For MacMillan, CREPE presented an opportunity to contribute to the advancement of policy thinking around water resource management, a relatively new area of interest for the CSO. Moreover, the prospect of taking part had also appealed to MacMillan's interest in broader policy debates around research funding, offering lessons about how funding worked, as well as the chance to be "part of an experiment, and all being well, to be on the sort of front edge of a wave of future initiatives" (MacMillan, T. 2013, personal interview, 29 March).

\footnotetext{
${ }^{3}$ https://foodethicscouncil.org/ Accessed April 10, 2019
} 
Santiago Ripoll, with a background in social justice and food sovereignty would join the FEC just before the project officially commenced, with the role of implementing the project that MacMillan had designed. Meanwhile, the research partner in the collaboration, the Fundación Nueva Cultura del Agua (FNCA), with its broad research mandate for water resource management (including development cooperation, environmental protection, and education), was essentially hired through a sub-contracting arrangement to provide data and to co-design/run two multi-stakeholder workshops. As MacMillan recalled of the initial meeting with the FNCA, the Spanish partners had come with some quite specific ideas of what they wanted out of it which didn't necessarily align that closely with the scope of what the FEC had originally prepared. As he explained, it became necessary to "broker an approach that worked and was feasible and would play to their skills and be something worthwhile for them to do, but was also aligned with the core of the project and feasible within the time frame and so on." Accordingly, the collaboration was ultimately the product of "a negotiation, a compromise more than a jointly conceived effort" (MacMillan, T. 2013, personal interview, 29 March).

Indeed, the necessity of accommodating the diversity of interests and approaches represented within the FEC and FNCA meant that compromise was central to the framing of the research project. Thus the FEC's goals of facilitating stakeholder engagement on a relatively new topic of interest had to be combined with the FNCA's academic objectives to conduct scientifically robust research on broadly defined principles of water resource management. Thus, a vital component of the study was a fieldwork component, including a two-day stakeholder engagement workshop in Almería, Spain. The workshop would serve as an important means of elucidating the causes and impacts of water scarcity in depth, from the perspectives of key stakeholders from policy, activist, and agro-business perspectives (CREPE 2010: 1).

The choice of Almería as the case-study site was intentional, as this notoriously water scarce Spanish province is home to a large part of the M\&S's produce supply chain. Louisa Nichols, at the time Head of M\&S's flagship environmental and social responsibility initiative, "Plan A", was keen to take part in CREPE after being approached by MacMillan. Having just completed a project with WWF UK on water foot-printing, the company had been struggling with interpreting a vast amount of data from six countries and hundreds of growers from within their supply chains. She explained, "whilst we seemed to be making some headway on water efficiency on farms... we realized we needed to look beyond the factory farm gate." Her motivation in taking part in the workshop in particular, was thus, "to try to understand the different perspectives that people had on water stewardship in the catchment area, to see if there was a common platform to act, and to explore what a common response might be." She added, CREPE offered "a way of seeing how [the FEC] could bring together a range of different stakeholders in a location and seeing what they could offer in terms of an international service" (Nichols, L. 2015, personal interview, 9 June).

With multiple interests and objectives at stake, the objectives of the workshop evolved to be ambitious, and somewhat nebulous:

- stakeholder deliberation (meeting and exchange to better understand the aims, concerns and interests of stakeholders in the Primaflor-M\&S supply chain);

- reflection on virtual water flows from Almería to the UK;

- exploration of the complexities of water management in Almería, avoiding myths and simplifications;

- deliberation on the different responsibilities and power relationships in the Primaflor-M\&S supply chain;

- and exploration of the possibility of further stakeholder meetings for decision-making. (CREPE 2009: 1)

However, as the narratives surrounding the workshops and what they achieved show, not all of these objectives were equally shared or met.

For Tom MacMillan, the FEC's Director, some of the most tangible outcomes of CREPE had accrued from working with M\&S and the opportunity the project had provided to offer a more participatory model for M\&S' work on managing the use of water in its supply chains. He opined, "We were very much helping them see the issues in terms of stewardship, more than sort of classic resource management. We helped them see it 
in qualitative terms, as understanding the sociology and politics of it...rather than seeing it primarily as a kind of life cycle assessment type issue." As for other project outcomes however, MacMillan was less enthusiastic. He stated, "I think [CREPE] equipped us better to contribute to discussions around water scarcity in the future, and maybe we can talk with a bit more authority because we're involved in such things", he continued, "but in terms of substantive learning or the development of new approaches, I don't think we gained much capacity out of getting involved in the project." In this regard, he concluded, "the return on FEC's investment in CREPE had been poor" (MacMillan, T. 2013, personal interview, 29 March).

On an organizational level this result was partly due the departure of Santiago Ripoll, charged with implementing CREPE, from the FEC to pursue doctoral studies. However MacMillan also spoke emphatically about the impacts of bureaucratic challenges stemming from the REA. Because of the change in organizational status, subsequent paperwork and funding delays, and onerous levels of financial reporting, MacMillan asserted, "There was little room for responsive, more opportunistic exploratory stuff...which is actually essential to making sure something like this has an impact." He continued,

Any responsiveness to opportunities relies on CSOs being able to investment time and money to cover that... and because there was so much uncertainty over the funding situation .... and the level of palaver over registering as the right type of organization, I think it diminished our capacity during the project. It was just such a hassle compared to kind of work we normally do. (MacMillan, T. 2013, personal interview, 29 March)

Nor did the FEC find itself in a position to continue engaging with the network of stakeholders it established in the region through its workshop with M\&S and others. Explaining why, MacMillan again pointed to REA-induced administrative burdens: "There were some interesting industry and NGO contacts in the south of Spain, and ideally, we would have ended up doing some further work in the area around water stewardship, but we were so frustrated by this experience that we didn't really want to see much of those areas in the immediate aftermath of that project." He lamented, "By the time the project ended we were quite keen to move on, so that meant we didn't follow up on some of the relationships we'd formed." The negative impacts of administrative strains were not limited to capacity building and networking outcomes either, also hindering the FEC's ability to reflect on and evaluate collaborative processes. Of the reflective diary writing exercise MacMillan acknowledged having access to others' diaries, but confessed there was no time to read them, conceding, "You could say that was poor time budgeting on our part...but because of the funding issue, we really didn't have the slack to get into that stuff...because it was taking more time than we had" (MacMillan, T. 2013, personal interview, 29 March).

In contrast, for Santiago Ripoll, having been directly involved in the implementation of CREPE, the most significant outcomes had accrued precisely in terms of capacity building/knowledge production. Of working with the FNCA for example, he asserted, "I learned a lot about virtual water, about water policy in Spain and particularly the problems of water scarcity in the south of Spain." Speaking specifically of his joint fieldwork with Maria Jesus Beltran in preparation for the workshops he stated: "That was when we really got to know each other better, and really, what each group was doing, and were able to put it all together." Ripoll also pointed to concrete learning from conducting stakeholder consultations, enthusing,

I gained a lot of skills in trying to look at things that seem difficult. [CREPE] has helped me to try to unpick all the different issues that make up an ethical problem, and to deliberate and discuss them. It allows you to look at things in a different light," he finished, "so from my point of view it was very rewarding. (Ripoll, S. 2013, personal interview, 9 May)

With regard to the degree to which the FEC had succeeded in shaping M\&S's approach to water stewardship however, Ripoll was less optimistic. He speculated, "I'm pretty sure the main driver of [multistakeholder] relationships is the buying department and the providers and that's all." Commenting on what M\&S' gained from taking part he mused, "I think they benefitted because there's this information that they want 
and can use, and these processes were the only way to get through some difficult problems." With regard to what had actually been achieved, he wondered aloud: "We did do this research, and we did raise issues around the demand side of water scarcity, but in order to be critical my question would be, has this actually changed the way that $[\mathrm{M} \& \mathrm{~S}]$ think about water?" If there had been a lack of impact on this level he speculated, it might have been a factor of the brevity of the engagement - while the workshops had been important in uncovering the various positions of a diverse group of stakeholders toward water scarcity, these revelations were just a stepping stone. To broaden the thinking of key participants such as M\&S, Primaflor and WWF Spain to considering working with demand-side solutions to water management would have required a much lengthier process of engagement, to establish longer-term relationships around which different options/alternatives could be explored. Yet, he cautioned, even if CREPE could have facilitated such a process, commercial pressures would likely limit the impact of those activities (Ripoll, S. 2013, personal interview, 9 May).

Much like Ripoll, research partners from the FNCA, Maria Jesus Beltran and Cristina Madrid also pointed to the power of the political-economic status quo. As Madrid recalled, "It was very difficult for M\&S in the beginning, because $[\mathrm{M} \& S$ ] were telling the producers that they had to use water better so they could sell environmentally responsible products, but $[\mathrm{M} \& \mathrm{~S}]$ didn't really know the reality so, it was really fulfilling, for me and the researchers to see this." She continued, "Maybe we changed [M\&S's] understanding of what water means in Spain, how it's not something that producers will waste because they have to pay for it and it's really precious, not only as a production asset, but also as a way of life." Of whether the engagement had affected Primaflor, Madrid was also cautious: "Maybe they just became aware that using water is not just good economics, but that it makes them more attractive to supermarkets in Northern Europe who are concerned about efficiency" (Madrid, C. 2013, personal interview 26 April). Maria Jesus Beltran was similarly cautious, pointing out that researchers had for years been providing demand-side solutions for water management. The problem, she asserted, was the difficulty in transforming research findings into policies, because in Almería as elsewhere, "the markets are only concerned with short term returns, and taking measures toward sustainability means thinking in the medium or long term" (Beltran, MJ. 2013, personal interview, 16 May).

This was most certainly the view of Marcos Dieguez, Director of Ecologistas en Accion, a local Almerían grassroots volunteer organization that took part in the deliberative workshop. Dieguez, in an interview on 20 September 2013 explained his organization's perspective, one that contrasted sharply with that of fellow workshop participants from M\&S and the WWF Spain:

Agriculture is the problem for us, not the greenhouses. The water footprint of each greenhouse is not too big, but there are so many of them. That's the problem. ...We know greenhouses save water, but there are too many of them, so their water consumption is too much, so we work on territorial planning. We fight against new greenhouses and try to convince farmers to change to ecological agriculture [sic].

While he had welcomed the opportunity to hear the views of supermarkets, it had been the chance to expose other workshop participants to their own more critical perspective that had drawn him to the event. Suffice it to say, Dieguez was not at all enticed by M\&S's proposal to lead a platform for action on water stewardship in Almería (Dieguez, M. 2013, personal interview, 20 September).

Louise Nichols of M\&S in contrast, had found participation in the workshop to be highly advantageous for M\&S, enthusing, "This project is helped us to learn something about what you need to enable a very broad group of different players around a water catchment to feel the need to act." The problem she surmised, came down to a lack of willingness to put a "true value" to water. She explained, "If you've got politics in the way, or a service provider who says don't worry, it's not a problem...you stop that collaborative debate happening." Not surprisingly, the workshops did not lead on to the continued engagement with the wider group that Nichols had hoped for (although M\&S continued working with their Spanish suppliers Primaflor, the WWF, and the FEC), however Nichols attested, "Without any doubt I learned something about stakeholder engagement, which no doubt has played a part in the way we now run our conferences and supply workshops on a range of issues. I think like all these things. You learn by something not working, how to do it differently" (Nichols, L. 2015, personal interview, 9 June). 


\section{EJOLT}

EJOLT was funded under the European Commission's Science in Society Capacities program (SiS2010-1.0.1) as a Mobilisation and Mutual Learning Action Plan (MMLAP). The MMLAP was at the time a new funding scheme that had evolved within the Science and Society program for pragmatic reasons. For one, it was hoped that the MMLAPs, which targeted (among others) previously EC funded projects, would enable a scaling-up of proven positive results (EC 2009). In addition, however, as an anonymous DG RTD official explained in an interview in March, 2013, the unit was undergoing restructuring, and it was hoped that fewer, larger projects would require less administrative oversight and the deployment of fewer EC project officers. Thus one of the criteria for project proposals was that consortia must comprise a minimum of at least ten independent legal entities established in at least ten different Member States or Associated countries (EC 2009).

In this context, EJOLT was designed and managed by a small team of renowned ecological economists led by Prof. Joan Martinez-Alier, based in Spain in the Department of Environment Sciences at the Autonomous University of Barcelona (ICTA-UAB). EJOLT aimed to build on the achievements of a predecessor project, CEECEC (Civil Society Engagement with Ecological Economics, 2008-2010), by facilitating mutual learning between a much larger consortium of researchers and activists in the study of a wide range of environmental justice conflicts. Initially, participation was sought from individuals with whom the project coordinator, Prof. Martinez-Alier, had close ties. Accordingly, many partners were already connected to varying degrees through a broad network that emanated from Martinez-Alier, and in part, from CEECEC, a predecessor project that he and I had co-authored and coordinated. To complete the consortium, additional partners were sought out and approached on the basis of their expertise in the thematic areas the project aimed to explore.

In all, twelve environmental justice organizations (EJOs) and eleven research partners spanning twenty countries and four continents committed themselves to EJOLT. Given the size and spread of the consortium, as well as the time constraints associated with putting together a detailed proposal for a three-year undertaking, the coordinators at ICTA UAB had to take a strong central role in the design of the project. Thus, initial plans were drawn up by the ICTA UAB academics based on their knowledge of various partners' competencies and interests and then circulated in an electronic document to all partners - academic and activist - with coordinators at ICTA UAB soliciting comments and input, usually via bilateral channels of communication.

In this manner, the EJOLT agenda evolved around two central objectives. The main aim from a research point of view was to highlight and analyze links between our growing global economy (characterized by everincreasing consumption rates of materials and energy), and an increasing number of ecological distribution conflicts at different geographical scales. At the same time, EJOLT (2010: 3) was designed to benefit EJOs that were keen to apply tools of the sustainability sciences in order to "empower EJOs and the communities they support that receive an unfair share of environmental burdens to defend or reclaim their rights." Thus, like CREPE, EJOLT's objectives (Figure 1) were implicitly political and egalitarian - to expose the roots of increasing ecological distribution conflicts as a means of transforming such conflicts into "forces for environmental sustainability" (EJOLT 2010: 3).

To achieve these goals, a total of twelve work packages (including project management) were designed (Figure 1). Unlike in CREPE where partners' collaborative engagements were mainly contained within one work package, EJOLT partners contributed across most of them. Cooperative activities were furthermore designed in a variety of formats, including in-person meetings and workshops; however, a great deal of work was by necessity carried out remotely, through electronic means such as email and Skype. The project launch meeting in Barcelona was a key event. Run over the course of several days, this meeting established personal relations among many partners who had never met but who considered themselves allies in a global struggle for environmental justice.

Without a doubt, EJOLT reinforced existing alliances between activists and among academics and CSOs (Clapp 2014). New partnerships were also forged, producing fruitful collaborations in follow up projects, notably revolving around an interactive Atlas of Global Environmental Injustices, The EJ Atlas (see https://ejatlas.org). However, as would become evident in the work package on Consumption, Ecologically Unequal Exchange and Ecological Debt, the gains from cooperative relations were sometimes made with great difficulty. 


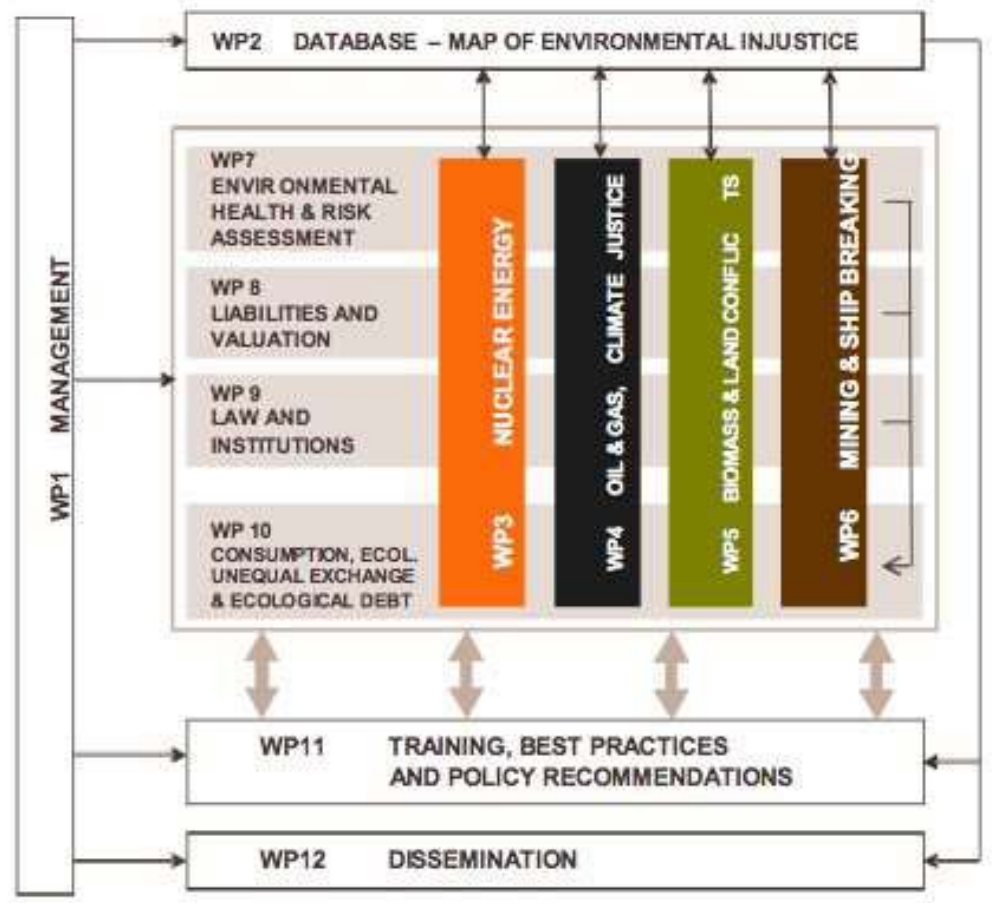

Figure 1: EJOLT: Structure and objectives. (EJOLT 2010)

\section{Ecological Debt}

The concept of ecological debt can be traced to the work of academics and activists in Latin America in the 1990s who pointed out that environmental problems that were evolving in the South were in fact the product of Northern industrial activity, and ultimately, historically exploitative economic relations between the two hemispheres. A seminal work in this regard was the publication of a paper by the Instituto de Ecologia Politica, entitled 'Ecological debt: a socio-political perspective.' In this paper, Robieto and Marcelo (1990) argued that the costs of ozone depletion should be borne by the nations that had produced ozone depleting chemicals and reaped associated economic benefits. This idea was widely taken up by Latin American NGOs, proliferating through campaigns across the Global South, and eventually gaining traction with some activist organizations and networks in the North, notably Friends of the Earth International (FoEI), Friends of the Earth Europe (FoEE) and the European Environment Bureau (EEB). Still, efforts to calculate ecological debt were (and still are) considered nascent, so with an increasing number of EJOs seeking to quantify such debts for awareness-raising activities, EJOLT set out to research "the roots of increasing ecological distribution conflicts at different scales" (EJOLT 2010: 4), by working with EJOs to co-produce and analyse data on ecologically unequal trade and ecological debt. However, as work got underway, tensions among a small group of partners began to evolve, tensions that would shape perceptions of the value and outcomes of the collaboration itself.

As the project unfolded for example, it became apparent that some Southern EJO partners were opposed to the quantification of ecological debts in monetary terms. Rikard Warlenius of Lund University soon found this out first-hand. A former trade-unionist, environmental climate activist, and journalist with work experience mainly in Sweden, Warlenius had been tasked with working with EJOs to co-produce knowledge on the effects of climate debt. As a doctoral candidate researching ecological and climate debt at Lund, Warlenius was well versed in technical aspects of these concepts, however, at his first EJOLT meeting with project EJOs in Durban, he received a rude awakening, recalling, "it was a tough discussion because I wanted to quantify this debt 
[monetarily] and some of the EJOs thought that this was a political concept, that it couldn't or shouldn't be quantified." He had certainly not been expecting such a reception, as he explained: "One might presuppose that [EJOs] will be happy for scholars to pick up on and try to elaborate and refine these concepts, and make them more useful", but as the meeting revealed, this was not entirely the case. Rather than exchanging views and knowledge to enable the calculation of ecological debts, the meeting evolved into a debate on the merits vs. disadvantages of doing so. Some EJOs for example argued that the monetization of such debt would legitimise market-based policy approaches, essentially undermining opposition to the commodification of nature, and more politically radical goals of reparation, and crucially, affecting wider systemic change. On coming to terms with such unexpected opposition, Warlenius reflected

I've learned a lot from the EJOs. They've definitely made me think more about the pros and cons of quantification and how I use these concepts, and to try to incorporate their methods for analysis into our work. It's a matter of who owns the concepts in a certain sense, so having this debate has been very valuable for me. (Warlenius, R. 2014, personal interview, 24 September)

This clash of perspectives carried over into other areas of Warlenius' work, as he had also been charged with co-authoring a book with EJOs on ecologically unequal exchange. Here, Warlenius and his Lund colleagues faced opposition from EJOs who felt the book was too theoretical and not practical enough to serve activist purposes. Understanding his task as one of producing a publication that would raise the profile and credibility of the concept of ecological debt, Warlenius recalled, "... when we took this preconception to meetings we found our vision clashed with what some of the EJOS wanted." He explained, "They wanted something that could be used for forming public opinion, for advancing their struggle, and shaping policies and so on." He conceded, "That is one of the purposes of course, but in order to do so, we might argue, you also need this kind of legitimacy within the scientific community, so that was a tension" (Warlenius, R. 2014, personal interview, 24 September). Of ongoing negotiations on the purpose and content of the book he mused, "I'm not sure where we'll land, or if everyone will be satisfied with the end product. We're in this process of debating. It could be something good because you reach out to a public audience and you put legitimacy in the project and so on, but on the other hand it probably won't be read as much as if we have a more popular version without all this formality." He added, "And this conflict is typical of EJOLT because we try to have both an influence on CSOs at the same time we want to have academic credibility and that is always not easy to combine" (Warlenius, R. 2014, personal interview, 24 September).

Also collaborating with Lund colleagues was Antonio Cardesa Salzmann of the University of Tarragona (CEDAT-URV), a Spanish institute specialized in international law. There, Salzmann had investigated the prospects for environmental justice under Spanish and international law but had never worked in a large transdisciplinary project on the topic, so for him EJOLT presented a very welcome opportunity. He recalled in a personal interview on 13 March, 2015, "this was completely new to us, and we hadn't so far looked into the way in which political economists, anthropologists, sociologists, or civil society pragmatically conceived this concept and how it operates." In this new context, one of Salzmann's roles was to carry out research with EJOs on the potential for developing and implementing an international legal framework for ecological/climate debt.

One such EJO partner was Ivonne Yanez, of Acción Ecológica. Of the feedback by Yanez on URV's first draft of the report however, Salzmann recalled a clear level of discontent, especially in reaction to the legal partners' scepticism over the operationalization of ecological debt under international law. He recalled, "Our view was that to make it operational under international law as it stands would require a complete reformulation of the fundamental premises of the international legal order." Admittedly, he also explained, the timeframe he had requested from Acción Ecológica to comment on the report had been narrow, with a matter of days before it was due to be finalized and published. This was in part due to language-related delays in drafting and editing the report, as URV had limited in-house English language competence. Even so, he went on, "When they wrote to us, we felt [the report] contained some things that were fundamental to us, and they were requiring changes to our report that we were not willing to do without discussion"(Salzmann, A. 2015, personal interview, 13 March). 
Yanez of Acción Ecológica recounted her perception of events vividly in an interview on 26 November 2014: "There was a misunderstanding, because they said something like please make your comments because tomorrow we have to send it for layout, and when I saw the policy recommendations they were so bad, so I said no sorry, we have to do this, we have to do that..." According to Yanez, their URV collaborators maintained that the report had indeed been sent earlier, but Yanez somehow had not received it. Whatever the case, she argued whether it had been sent or not was beside the point. She asserted, "Even if they sent this before they didn't follow up, so for me this was the worst experience, because it was supposedly a policy recommendation of all the groups in EJOLT but it was not something I was going to back. So of course it was a huge debate" (Yanez, I. 2014, personal interview, 26 November).

With both parties liaising with project coordinators to express their concerns, a compromise was reached whereby URV's report would go ahead, but a separate report focused on policy recommendations by EJOs would also be published. This was seen as satisfactory by Salzmann, who admitted,

We didn't make enough effort to contact CSOs, because not many of them were very engaged in transnational litigation. We should have planned the feedback process, not only with the academic partners but also with the civil society partners, in greater detail, and that's a critique that we make of our own work.

He continued, "This is also a legal academic culture problem I would say, because, at least in Spain, conducting interviews and getting feedback from external actors is not really part of how we work, but this is definitely one thing that we are trying now to change." Reflecting further he added, "We also acknowledge that the concept of ecological debt is very much their construction and we accept that [they] have very strong feelings on that" (Salzmann, A. 2015, personal interview, 13 March).

Considering the range of tensions that emerged surrounding work on ecological debt, the partners' perceptions of what had been achieved through EJOLT remained overwhelmingly positive. As Rikard Warlenius attested, "The up side was greater than the down side. I have been impressed with many of these EJOs and their ways of working. I very much respect them, what they do and how they work." However, he added, "It has also become clear to me that this exchange and collaboration between academia and activism is not easy all the time" (Warlenius, R. 2014, personal interview, 24 September). Salzmann, of his experience noted, "Beyond the tension I would say that this has been an extremely positive experience for us" adding, "these problems arise in all research projects. Our general aim was to broaden our perspective and to learn about working processes in European research projects and we achieved this." He effused, "EJOLT has very much opened up our minds and broadened our methodological approaches, our internal procedures and the way we work still have to change quite a bit", pledging, "we have to abandon this isolation, this autonomous way of working, and in this sense EJOLT has completely changed our research agenda" (Salzmann, A. 2015, personal interview, 13 March),

Yanez for her part also conceded, "I think this was resolved. We really had to intervene and the recommendations were not completely perfect, but of course this is a coalition of groups and we discovered some basis of agreement and it was good in the end." She was also adamant though that the majority of tensions could have been avoided with better communication, and more clearly defined processes of collaboration and management: "These issues should have been discussed before. The decision-making process was not there." Yet Yanez too remained positive on the whole, insisting "Acción Ecológica is always trying to look for alliances, and have discussions, and even with the debates around the polemics and discrepancies it was good, because this is how you talk and you make progress in the movement, no?" (Yanez, I. 2014, personal interview, 26 November).

On the whole, Yanez believed Acción Ecológica had been a net contributor to, rather than a benefactor of EJOLT. To her mind, Acción Ecológica had played an important role in shaping debates and raising the awareness of other partners, especially academics: "I think that we really shifted completely the conception of the reports, and discussions about issues of ecological debt." She insisted, "but for us actually, very little has 
been influenced by EJOLT." This had to a great extent to do with English being the publication language of the reports, which her organization could not afford to have translated into Spanish, an issue she was emphatic about: "This is a recurrent point, a very key point. If they are in English nobody will read them. You have 350 million people in America Latina that probably cannot read English, so a whole continent is excluded from the possibility of using the documents." Still, EJOLT had provided a valuable opportunity for Acción Ecológica to join forces with Northern academics and EJOs, enabling new political alliances for social change. Such work she explained, necessitates not only understanding the historical and colonial relations between North and South, but also the realities of how each other's institutions and organizations work. In this sense, EJOLT, she finished, had provided a wealth of opportunities for learning (Yanez, I. 2014, personal interview, 26 November).

\section{GAP2}

GAP2 (SiS-2010-1.0.1 - MMLAP), sought to promote processes for open and effective participation of fisheries stakeholders in research and management. Also an MML project, GAP2 was shaped by an awareness of the poor state of European fish stocks due to overfishing, wasteful practices, and the exclusion of community and wider environmental concerns from centralized management systems based predominantly on biological science (GAP2 2014). In response to what was seen as a long history of negative incentives for fisheries management in Europe, the overarching objective of GAP2 was thus also political. Indeed, GAP2 evolved in a policy context in which the European Union was preparing new legislation to ban the practice of "discarding" or throwing unwanted catches of fish back into the sea, "either alive or dead, because they are too small, the fisherman has no quota, or because of certain catch composition rules" (European Commission nd). The impending region-wide discard ban was viewed with a great deal of trepidation by fishermen, seen as costly in terms of their livelihoods, but also unnecessary and unresponsive to local conditions. Designed to "demonstrate the role and value of stakeholder driven science within the context of fisheries' governance"(GAP2 nd: 2) this project set out to support active participation and knowledge sharing between scientists, stakeholders and policy makers as a means of reducing tensions and building relationships able to yield long-term benefits to the sustainability of European fisheries.

The development of GAP2 was led by Steve Mackinson, an expert in fisheries science and management at the Centre for Environment, Fisheries, and Aquaculture Science (CEFAS) in the UK. GAP2 had in fact been preceded by another FP7 project, GAP1 (April 2008 - Sept 2009, also coordinated by Mackinson), a shorter, exploratory project designed to identify complementary forms of knowledge and shared concerns as a basis for building cooperative relationships. Building on the accomplishments of GAP1, GAP2 thus set out promote greater stakeholder participation in the production of policy-relevant knowledge, and in structures for the governance of fisheries and marine environments (GAP2 2014). These goals would be achieved via the pursuit of five objectives (see Figure 2), the fifth of which entailed conducting collaborative research between scientists and non-scientists (see Figure 3), through the joint selection, planning and implementation of case-study research. "Participatory action in research and decision-making" was fundamental to the GAP2 methodological approach, "enabl[ing] partners with various perspectives but common interest to collaborate in mobilising and constructing knowledge and in using it to make decisions" (GAP2 2014). However, as the study of efforts to develop a fisheries-based system for monitoring coastal cod in Norway illustrates, the degree to which partners were enabled to contribute to the construction of knowledge, or to use it as a basis for decision-making, was disappointing for some. 
GAP aims \& objectives delivered through WPs

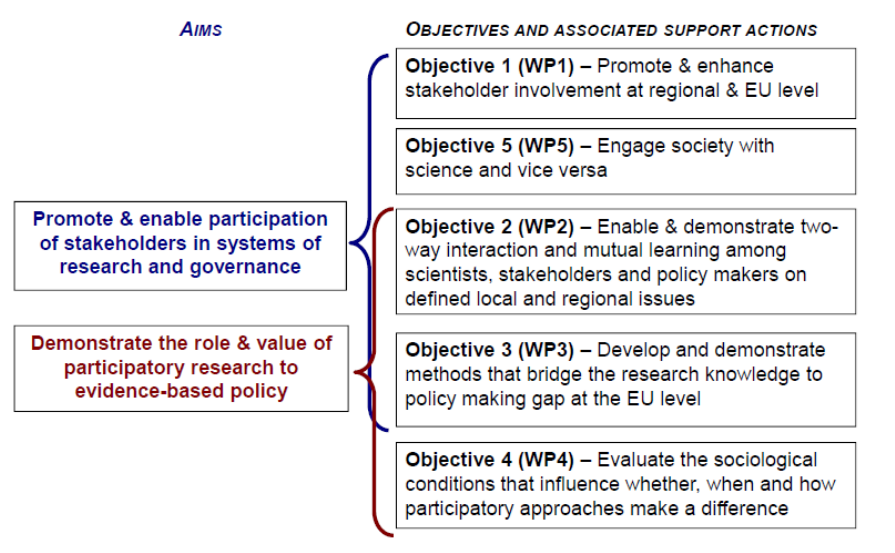

Figure 2: GAP2 Objectives. (GAP2 2014)

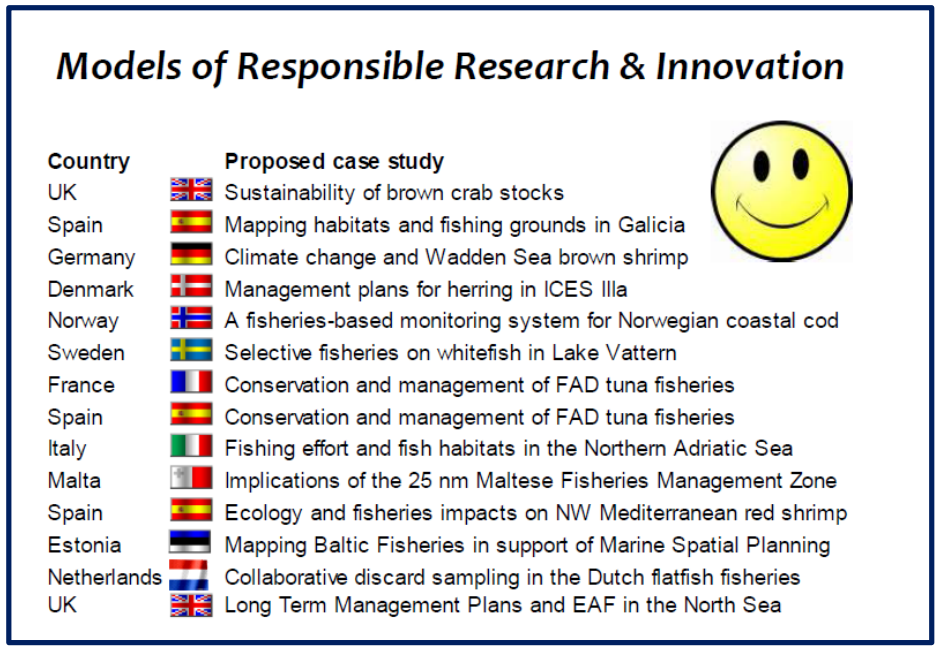

Figure 3: Full list of GAP2 case studies. (Gap2 2014)

\section{Developing a fisheries-based resource monitoring system for Norwegian coastal cod}

One of the collaborative case studies of GAP2 was situated in Norway, and revolved around the collaborative development of "a robust and effective fisheries-based monitoring system for coastal cod resources" (GAP2b nd). Professor Petter Holm of the University of Tromsø (UiT) had an interdisciplinary social science background, and had worked at the Norwegian College of Fisheries Science there since 1987. Aware of the European policy trend toward opening up knowledge production and processes to wider stakeholders, and motivated by his long-standing interest in the local knowledge of fishermen, Holm was keen to explore how this new directive could be operationalized in an industry that had traditionally excluded the lay knowledge of fishermen (Holm, P. 2015, personal interview, 26 November). Holm had also been a participant in GAP (the predecessor project of GAP2) which had enabled him and his Tromsø colleagues to establish relations with the Norwegian Fishermen's Association (NFA), represented by local Coordinator, Jan Andersen. 
For Holm, GAP2 presented an important opportunity to transcend established dynamics of interactions between fishermen and scientists, whereby "the fisherman has a boat, and the scientists bring on board the equipment and do the actual data collection." Additionally however, Holm hoped GAP2 would allow him to explore other areas of teaching and research in Science and Technology Studies (STS), namely, how science is used in political settings and for resource management (Holm, P. 2015, personal interview, 26 November). Jan Andersen of the NFA also had high hopes for GAP2. As a professional coastal cod fisherman since 1968 and a strong advocate of fishermen's lay knowledge, he asserted: "The project was in my opinion not only interesting but absolutely necessary." He explained, "I always thought that oceanographers are living in their own world, high above the fishermen's opinions. They have not been interested in using fishermen's knowledge accumulated over a century of work at sea." For Andersen, the purpose of GAP2 had been one of establishing collaboration, building trust and "reducing the gap in the perception of reality between fishermen and scientists" (Andersen, J. 2016, personal correspondence, 25 May). However, as this study shows, as GAP2 progressed, the core focus and aims of this collaborative project would evolve in unexpected and ultimately disappointing ways.

The initial phase of GAP (April 2008 - Sept 2009) Holm recalled, was characterized by very egalitarian processes, with the NFA very much in the driver's seat of the case study design. The rationale for this approach, according to Holm, was underpinned by partners' jointly held view that "fishermen have a lot to say, and that they would not only be performing scripts written by scientists, but that they could be able to do [the research] themselves (Holm, P. 2015, personal interview, 26 November). Andersen concurred with Holm's account of the positive nature of early-stage working relations, confirming "In the beginning we had many meetings of the management team to discuss goals and cooperation" (Andersen, J. 2016, personal correspondence, 25 May). As work progressed however, partners became increasingly cognisant of the fact that if the data to be produced by fishermen were to be accepted by credible and relevant scientific bodies, such a partner should be invited to collaborate in the case study. Thus just as GAP2 commenced, partners from the UiT and NRF approached the Norwegian Institute of Marine Resources (IMR), the largest and most authoritative research, advisory and monitoring centre in the country, to join the project. The IMR accepted. This decision would prove to shift the balance of cooperation significantly, leading to unexpected tensions given the groundwork laid in GAP.

This move to engage IMR in itself was not a source of tension, having been mutually agreed by Holm and Andersen. As Holm explained, indicators for assessing stocks of coastal cod were relatively simple, and he and Andersen had been confident that there was sufficient scope for collaboration to improve data collection infrastructure, and to establish more participatory methods. Problems did arise however with the realisation that the project timespan of four years was too brief to produce a credibly long-term set of indicators. Holm lamented, "What we could do was just so little compared to what we would have needed in order for this time series be of any use" (Holm, P. 2015, personal interview, 26 November). It therefore became necessary to reorient the study to produce data that would be considered useful by the wider scientific community. The solution to this dilemma came from the IMR, who proposed integrating lay-knowledge with a predominantly technical approach. It was decided that the expert knowledge of fishermen would be used to map the location of stocks and spawning areas, and that Andersen's fishing boats would be equipped with IMR-compatible sonar technology to echo-locate cod stocks, and crucially, to distinguish between two closely related species: coastal cod and north-east Arctic cod. This distinction it should be noted, was an IMR, rather than a GAP2 research priority, as the former had been eager to assess the impact of coastal fish on the spawning activities of the north-east Arctic cod in the Vestfjord. Data collected by the fishermen would then be passed to IMR scientists for validation and processing (GAP2b nd).

Of this new trajectory Holm recalled, "We started with the intention of making the fishermen an equal partner, but as it turned out, we were all caught up by this logic of science, and we had to do the science as the marine biologists told us it should be done." He elaborated, "In the end we learned that in order to be useful, for the results to be picked up, we had to follow the rules, and the rules are made by the established marine scientists." The partners from UiT and NFA were faced with a fundamental and sub-optimal compromise, as Holm explained, "We ended up in a sort of deference mode, of ceding to established science. The scientific structures were too strong for our small project. We could have chosen to be irrelevant of course... and do our own thing, but that wasn't a very good option either" (Holm, P. 2015, personal interview, 26 November). Thus 
the focus of collaboration shifted significantly from the initial goals of relying on lay knowledge to improve indicators and methods of data collection of coastal fish stocks, and to identify and locate under-fished species, to one in which fishermen's knowledge would be used instrumentally to fulfil wider IMR research objectives. This modified approach furthermore was justified through a discourse that promised to "empower" fishermen with experience-based knowledge, should they choose to adopt "the same type of strategies [as scientists]" (GAP2 2011). By April 2012, the "empowering" process of data collection had begun in earnest.

This change in strategy represented a significant departure from the plans originally formulated between UiT and the NFA, but both Holm and Andersen remained philosophical about the experience. As Holm recalled during the interview on 26 November 2015, "There was some disappointment. It had been a failure in the sense that we hadn't achieved what we set out to do, but we weren't angry with each other. We were in agreement." Similarly Andersen testified. "The practical cooperation with oceanographers at the University of Tromsø was always the very best" (Andersen, J. 2016, personal correspondence, 25 May). Nor did the partners give up on their original aim of building the capacities of fishermen participate in, and even lead research processes. For example, Holm and Andersen conceived of establishing a Centre for Experienced Based-Knowledge in Steigen that would be owned and run locally by fishers to strengthen links between the expertise of fishermen and scientists (GAP2 2013). To their disappointment however, this initiative did not bear fruit due to a lack of interest on the part of funders. As Holm recalled, "When we came with this great project to have the fishermen do their own research, they said this is not on our agenda, in our strategy, so we couldn't get anything out of them" (Holm 2015, personal interview, 26 November).

Despite the lack of success with original goals, Holm was philosophical about what GAP2 had achieved, pointing to valuable lessons. One of these was about the importance of understanding the local research policy context. He for one had not been fully aware of the strength of the IMR as an institution in Norway and its central and historic role in the management of fisheries there. The fishermen's trust in science and in IMR, he explained, was very strong. "For over 100 years stocks have been well managed, and everything is working, so there is not this crisis context that you find in some other countries, and there's this centralized, very strong fishermen's association, that actually prefer to have the IMR take care of knowledge production." Still, he maintained, "The end product was good. It wasn't the result we had set out for, so I'm not that happy with it as you understand, but that was what we could achieve." Reflecting further, he added, "I actually said in the beginning at a meeting that it would be great to have studies that succeeded, but I also hoped that we would have some spectacular failures, because that would help us to identify the barriers, the problems, the challenges for this type of thing" (Holm 2015, personal interview, 26 November).

Another lesson had been about the complexity of cooperative processes themselves, and how the integration of various partners' expertise required, not bring to the table, but a setting aside of partners' preexisting knowledge. He explained, "What matters is not what you already know, but what you don't know." He elaborated, "You're trying to solve problems together and cooperate to gain new insights, and in that process, researchers and fishermen need to put aside what they think they know, and how to do that is very complex. There's no standard answer to how to do that." In GAP2 this meant partners "spent a lot of time learning what was going on, learning a common language, and it's always a struggle and a lot of work. That's just how it is." He added, "I don't mean to complain. It's the crossing of disciplinary boundaries, the accommodation of new people. It takes time, and you need be prepared for many fruitless, frustrating conversations, but if you can take that, eventually good things happen" (Holm 2015, personal interview, 26 November).

Finally, his experience in GAP2 had led him to think much more critically about the European research policy imperatives for opening the governance of research to wider stakeholder participation. Before this trend, he recounted, marine scientists had rejected fishermen's knowledge as anecdotal. Now however, in part due to new funding criteria, "they're in a situation where they need to cooperate with stakeholders. So they cannot speak about or to fishermen in the same way as they did before." In one sense Holm mused, this change in attitudes and relationships had undermined the more radical aspirations of GAP2 - whereas not so long ago such a project would have been regarded as controversial, GAP2 aims were now subsumed by new governance norms of participation and inclusion. In this new research policy context Holm asserted, the challenge for scientists like himself was less about convincing researchers of the need to democratize research, and more about ensuring that the participation and inclusion of wider stakeholders in research was meaningful. Reflecting 
on his own experience, Holm was justifiably sceptical about the extent to which projects like GAP2 could transcend the tendency toward, "superficial, pretend participation" to actually transform entrenched management systems like those of IMR, such that fishermen might contribute to processes of knowledge production and management, in a meaningful way. "That's an issue", he asserted, "and as I understand it, that's what GAP2 is about, developing an infrastructure where fishermen and other stakeholders are not excluded from knowledge creation, but are partners in that" (Holm 2015, personal interview, 26 November).

Without a doubt then, Holm remained convinced of need for projects like GAP2, but if they were to be useful, he asserted, researchers really needed to ask questions about what participation is, how can it be done, and what kind of systems need to be in place for participation and representation in order to go beyond pretence. These, he asserted were the really important questions that would guide his work in future, how to engage stakeholders "in an effective and democratic way, in a way that makes a difference." As for the experience of the fishermen in the project he speculated, "There have been no real results that can be used for anything." Perhaps, he ventured, "they have learned something about how science works, and how to do this cooperative stuff", he continued, "but as for whether it's been useful, I'm sure it was disappointing from their point of view" (Holm 2015, personal interview, 26 November).

Indeed, as the testimony of fisherman Jans Andersen would reveal, very little had been gained in practical terms as a result of his organization's reformulated role in GAP2. In Andersen's opinion, the interest of IMR in the cooperative aspect of their work together waned soon after work had begun. Of his initial aspirations to work with IMR oceanographers to ascertain the size of fish stocks and to gather evidence that would enable the commencement of commercial fishing of under-exploited fish species, he lamented that the IMR scientists were not interested. Nor he maintained, were they interested in fishermen's knowledge. He explained, "They were only concerned with calculating coastal cod numbers outside Steigen, and whether they interfered with Barents Sea cod when entering the Vestfjorden for spawning, so they would decide where and when we collected data, and when it was sent to the [IMR] researchers. We lost all sense of ownership of our data" (Andersen, J. 2016, personal correspondence, 25 May).

Similarly to Holm, Andersen was both disappointed and surprised by the low level of interest in GAP2 activities, not only on the part of the IMR, but amongst other fishermen's organizations and policy makers. The problem he speculated, was essentially a credibility issue. For him, the gap between the scientists and fishermen was simply too great and bridge-building had hardly begun. Asked if he felt that project goals had been achieved, Andersen replied flatly, "No. I felt that the main purpose of the project had been to develop better collaboration between fishermen and scientists in the production and use of data that the fishermen had collected, but nothing was resolved" He finished, "As we did not solve the conflict", he finished, "we did not have any useable result of GAP2" (Andersen, J. 2016, personal correspondence, 25 May).

\section{Discussion: the nexus of power in TDR - people, processes and policy}

As the accounts of CREPE, EJOLT and GAP2 have shown, despite the best intentions of TDR participants to collaborate around principles of egalitarianism and mutual benefit, tensions pervade TDR projects, giving rise to struggles among participants over the meaning of projects themselves, and their outcomes. Without a doubt, some of these tensions result from the effects of "too many cooks", as varied interests, objectives and cultures inevitably clash when the efforts to compromise fall short (Mosse 2005). Yet the projects studied here also demonstrate that in TDR, power frequently circulates across multiple scales, flowing from differences between individuals with conflicting priorities, into cooperative processes at all stages of the project cycle. Tensions at the level of individuals and project processes were exacerbated by the structures and conditions of wider policy contexts within which projects were embedded. The implications of this dynamic are significant, meaning that participants in TDR projects must surmount a complex set of interrelated challenges in order to achieve mutually beneficial, transformative results.

\section{People}

Arguably, the line between researchers and CSOs has become blurred (Casas-Cortés et al. 2008), as both increasingly share concerns with "causal inference" (Roper 2002), use similar methods to produce 
knowledge (Stevens et al. 2013), and share an insistence that research results "serve the needs of contemporary and future movements for change" (Edelman 2009: 249). Even so, as Edelman (2009: 246) notes, academics and non-academics on the whole "occupy different social roles and institutional spaces and emphasise different kinds of social action." Accordingly, tensions arise in TDR projects among individuals acting as agents of organizations with distinct organizational logics, cultures and priorities.

Indeed, clashes between institutional priorities, logics and cultures were common across CREPE, EJOLT and GAP2, albeit in different ways. In both EJOLT and GAP2, projects conceived of and managed by academics, a bias toward the development of theory and the production of scientifically rigorous research came into conflict with CSO goals of practical problem solving (Roper 2002). The case of EJOLT in particular highlighted how tensions can emerge in TDR when academics prioritize writing for other academics, whilst CSO partners prefer to publish for the widest audience possible, translating project outputs into the language(s) of CSO constituents to ensure broad access to project outputs (Edelman 2009). The case study of GAP2 meanwhile became a site of scientific/CSO tension when the research priorities and methodological preferences of the IMR superseded the more practical and democratising goals of the NFA. CREPE in contrast was somewhat atypical. Led by a CSO instead of an academic partner, the FEC's goals were shaped by their organizational priorities of stakeholder engagement, but also arguably, by a pre-existing alliance with influential FEC stakeholder M\&S. Thus in the workshops in Almería, little progress was made in terms of the CSO's more transformative objectives, with tensions between the corporate objectives of the supermarket and some CSOs precluding the possibility of further critical engagement on water resource management.

There were also notable tensions between the way academic and non-academic partners engaged in discourse and debate. As Roper (2002) observes, academics tend to deploy discursive styles and approaches that advance theoretical approaches and fuel debate, while CSO actors tend to value more participatory and consensual forms of discourse. This sort of tension surfaced noticeably in EJOLT, when Acción Ecológica's Ivonne Yanez found the degree of engagement by - and interaction with - academic partners from Lund and URV to be lacking, but also in GAP2, when the Jan Andersen realized that the IMR had clearly lost interest in engaging directly with the NFA. Conflicts between discursive styles emerged in CREPE as well, but not as they might have been expected to in a collaborative CSO/research partnership. In this case, aims of the FEC and FNCA to promote more critical, politically sensitive perspectives around water resource management were incompatible with M\&S' preference for a depoliticized "collaborative debate" (Nichols, L. 2015, personal interview, 9 June) around a decidedly narrow (supply-side oriented) conception of water resource management.

Conflicting priorities among actors are relevant in their own right, as they can, if not successfully negotiated, seriously impede working relations among individuals. However, these tensions are also significant in terms of their potential to flow into and erupt within wider cooperative processes, impeding the integration of diverse forms of knowledge, hindering mutual learning, and ultimately, producing struggles over project outputs, outcomes, and even the very meaning of projects.

\section{Processes}

Clearly, TDR processes, while offering potentially fruitful means for solving complex sustainability related problems, are still in their infancy, particularly with regard to integrating CSO perspectives and approaches with those of academics (Görg et al. 2014; Spangenberg 2011). Some scholars have attributed challenges such as those arising in CREPE, EJOLT and GAP2 to methodological teething pains (Pohl and Hadorn 2008), or to cultural clashes (Edelman 2009; Roper 2002). However, it is my view that many such tensions should be seen as political matters, namely, struggles over whose priorities and criteria for relevance count. Indeed, as Jahn et al. (2012: 3) observe, although "the idea of mutual learning comes with an egalitarian impetus", in practice it "all too often is retarded by power asymmetries."

Divergent opinions over the value of project results, for instance, can be traced to governance arrangements established in initial crucial phases of projects, when a homogeneous set of actors is in control of framing the core research problem and shaping the overall work plan. This stage, as (Lang et al. 2012: 28) observe, entails several crucial activities, including the: 
...identification and description of the real-world problem; setting of an agreed upon research object, including the joint formulation of research objectives and specific research as well as societally-relevant questions; the design of a conceptual and methodological framework for knowledge integration; and the building of a collaborative research team.

Political tensions can thus be hard-wired into TDR projects when insufficient measures are taken to ensure diversity and inclusivity of the widest possible range of partners at the earliest stages of project conception. As the cases of CREPE, EJOLT and GAP2 have shown, this omission can result in "lack of problem awareness", "insufficient problem framing", or "unbalanced problem ownership" (Lang et al. 2012: 35-36), any of which provide fertile ground for mismatched expectations during project implementation.

Indeed, contrasting expectations proved a source of tension in the cooperative processes of the projects examined here. Such tensions arose in particular when mutual learning processes were impeded by the lack of a common language, an "ubiquitous complication" (Pohl and Hadorn 2008: 115) that arises when some partners are unaware of the meaning of others' terms, or of how meanings change depending on context. The lack of a common language around "water scarcity" certainly posed challenges within CREPE, precluding further collaboration among stakeholders assembled for the workshops in Almería. The same was true of differences between EJOLT academics and activists of the Global South over the concept of ecological debt. Similarly, in GAP2 divergent interpretations of "the integration of lay knowledge" meant that rather than becoming empowered, the fishermen of the NFA found their research objectives marginalized by the IMR. Rather than dismissing these tensions as challenges that are methodological (Pohl and Hadorn 2008) or even cognitive (Görg et al. 2014), these should be seen as symptomatic of a more pernicious problem, namely, the tendency of more powerful actors in TDR to "assume that they may speak in the name of those on whose behalf they claim to work" (Edelman 2009: 260). Indeed, as Russell et al. (2008: 468) note (citing Notowny et al. 2001) in TDR, "power certainly matters." Indeed, "if the interests of different partners in mutual learning are different .... and if power differentials exist (as they generally do), mutual, consensual outcomes are by no means guaranteed."

The impacts of unbalanced problem ownership and absence of a shared language furthermore extend to the final stages of TDR projects, where the task is to re-integrate, disseminate and apply newly co-created knowledge. Tensions arose in the projects of this study when outcomes were perceived as illegitimate or seen to "interfere with legitimized procedures and official politics" (Lang et al. 2012: 39). That the relationship between producing and implementing research findings is far from one of "linear input-output", but rather a "deeply political" affair (Aniekwe et al. 2012: 10) became apparent in EJOLT when Ivonne Yanez of Acción Ecológica rejected the policy recommendations and publication orientation of academic counterparts in EJOLT; when efforts to secure a more prominent role for the lay knowledge of fishermen were rejected in GAP2; and in CREPE when grassroots organizations rejected the supermarket's overtures for establishing cooperative relations around supply-side water resource management. Clearly, unbalanced problem ownership and absence of a shared language leave TDR projects vulnerable to a multitude of struggles (whether explicit or uncommunicated) over "what knowledge to produce, how to produce it, who should produce it, what to do with it, and who 'owns' it once it is produced" (Edelman 2009: 260).

\section{(Research) Policy}

Without a doubt, the circulation of power at the level of individuals and at project level has profound impacts on how partners perceive the meaning and outcomes of the TDR projects to which they contribute. However, there are considerable impacts of the wider research policy context within which TDR projects are embedded and the constraints this context imposes upon individuals and processes. In this regard, many critics have pointed the finger at what they perceive as inherently flawed funding instruments. Görg et al. (2014) have written extensively on the structural aspects of funding mechanisms, arguing that effective integration demands not only adequate time but also resources for joint problem formulation from the earliest phases of project conception and design. However, they point out, funding conditions and criteria are often incommensurable with prerequisites for TDR research, a mismatch that renders integration problems inevitable. 
As Aniekwe et al. (2012: 16) observe, a key problem in the past has been that those who hold the purse strings are not sufficiently aware of the complexities and demands posed by collaborative work, and they fail to appreciate the reality that "the costs of setting up and managing collaborative research are higher than more straightforward research projects and need to be built in from the outset." For CSO partners, especially those for which research is not a core activity, the constraints in terms of resources for proposal development, as well as ongoing financial and other report writing, are great even under normal circumstances. This was certainly the case for all of the projects in this study, requiring academic partners to lead such processes in all projects. However, the decision of REA officials to re-categorise the FEC had a tremendously deleterious impact, not only on what that organization had hoped to achieve, but on its ability for and even interest in reflecting on what was not achieved, and why not.

Nor are European funding schemes designed to adequately support the necessary levels of communication between research and CSO partners. As Görg et al. (2014) observe, effective communication requires transcending the typically "linear" procedures for outreach and dissemination followed in conventional project management (2014: 337). Academic veterans of TDR repeatedly emphasise the importance of joint reflection on TDR processes themselves (Görg et al. 2014; Jahn et al. 2012; Lang et al. 2012; Pohl and Hadorn 2008; Settele et al. 2010), yet funding programs, at least at the European level, have so far not taken such calls to heart. Indeed, in all three projects examined here, participants expressed how utterly crucial it is to adequately finance costs in terms of time and resources for communication among all partners at all stages of the project cycle, from joint problem framing, to implementation, and beyond, to the dissemination phase. Ample budgetary support is particularly important in the latter phase (as the case of EJOLT demonstrated resoundingly) when CSO partners' constituents communicate in languages other than English, the working language of EC funded projects.

Part of the problem would seem to be, then, that regional funding schemes such as the European Framework Programme have not adequately evolved to support the unique demands that transdisciplinary work entails. Such a state of affairs accordingly begs the question of why not. Indeed these issues were raised and documented in several program evaluation workshops run by DG RTD and attended by CSO and academic participants in FP7 programs (EC 2006, 2010, 2012b). The answer to this question, some scholars argue, is attributable to the prevalence of an instrumental approach to TDR among policy makers, the origins of which lie in the political-economic roots of research policy in $19^{\text {th }}$ century liberal market economies. In that era, policies were designed to harness the natural sciences and technological advancement for the development of industrial production and welfare economics (Hadorn et al. 2008). As the political economies of modern western democracies have developed, it would seem that instrumental approaches to scientific knowledge have persisted, but with a new focus on an agenda of ecological modernisation, and the achievement of what are valorised as the mutually beneficial goals of economic growth and environmental protection (WCED 1987; Mol 1995; Hajer 1995; Murphy and Gouldson 2000).

This is certainly a critical perspective shared by many scholars familiar with the evolution of TDR in the European context. These observers describe the approach to promoting TDR and other forms of participatory research as paternalistic (O'Connor 1999), exemplifying a form of "adaptive learning", whereby the discourses of research funding institutes are merely adapted to existing cognitive frameworks, policy objectives and causal beliefs, without changing dominant interpretations of organizational purpose (Siebenhuner 2008: 96). Thus, while funding instruments can serve as key drivers of collaboration, they can also act to constrain innovative collaboration "when funders set the agenda" (Aniekwe et al. 2012: 16). In this sense regional programs that claim to value and support the practice of TDR under an agenda of "ecological modernisation" can perform rather innocuously, as "technologies of government", instrumental to the exercise of "legitimate and calculated power... mak[ing] the objects of government thinkable in such a way that their ills appear susceptible to diagnosis, prescription and cure by calculating and normalizing intervention" (Rose and Miller 1992: 183).

In science and technology studies (STS) language, this becomes possible, for example, through research calls that problematize issues around sustainability in a particular manner (Callon and Law 1982), enrolling a wide variety of actors by providing opportunities to collectively "participate in the construction of facts" (Latour 1987: 108). In this context, processes of "translation" (Callon 1986; Rose and Miller 1992) are 
deployed that create "associations between heterogeneous entities, defining their identities and the roles they should play, as well as the nature of the bonds that unite them" (Callon 1986: 24).

Key to this line of argumentation is the view that processes for enrolling different actors in TDR programmes entail an extension of accountability, a sort of "responsibilization" (Maasen and Lieven 2006: 401) of all involved, which depends at the micro-level "on each member's willingness and competence to assume extended responsibility for both the research proper and the usefulness of its results." The acceptance of TDR as a form of research is thus predicated at a macro level on society's acceptance of itself as "an audit society", in which "transdisciplinarity can be regarded as a further element of audit...designed to bring scientific and societal goals into mutual agreement" (Maasen and Lieven 2006: 406). Since TDR is increasingly propagated and performed in the context of societies characterized as neo-liberal", the argument continues, "the task of producing 'socially robust knowledge' ...couched in terms of extended responsibility of science in society, can also be regarded as a specific neo-liberal rationality in science policy" (Maasen and Lieven 2006: 407). In this sense, transdisciplinarity completely loses its transformative capacity to become a full-fledged instrument of "governmentality" (Burchel, Gordon and Miller 1991) metamorphosing into "a new mode of governing science in society" (Maasen and Lieven 2006: 407) in the context of modern science-society relations that are increasingly difficult to manage.

Central to this notion is the role such programs play in the generation of trust. Authors such as Wynne (2006), Irwin (2006, 2008), and Borchelt et al. (2010) have written extensively on the utility of initiatives for public engagement in science for restoring public trust in science and legitimizing policy, especially in the face of growing unease over particular techno-scientific trajectories in what is increasingly characterized as a "risk society" (Beck, Lash and Wynne 1992, Beck 1999; Giddens 1995). Trust is generated through processes of translation and stakeholder deliberation, whereby "scientifically sound" applications emerge, whilst input from non-scientific stakeholders essentially becomes invisible. What remains evident they point out, "is the participation itself" (Maasen and Lieven 2006: 406), as "microcosms of visible research" (p. 407) generate public trust toward decision-makers. Indeed, the funding of CREPE, EJOLT and GAP2 have enabled the European research policy community to lend "visible" support to projects with radical policy objectives (for example, questioning the development of a European "bioeconomy", recognising the concept of ecological debt on a global institutional level, and localising the management of European fisheries management, whilst leaving dominant, neo-liberal policy trajectories of ecological modernisation intact.

Cumulatively, these perspectives on power and governance inherent in European approaches to TDR point to a perspective of "co-production", which asserts that the production of knowledge and social order are intertwined. Jasanoff $(1996,2004)$ has long argued that science and policy relations have evolved as processes of state-making have increasingly incorporated processes of knowledge production. At the same time, the making and use of knowledge has been increasingly influenced by governance practices. Within this dynamic, TDR, effectively becomes a political tool, "indispensable to the expression and exercise of power" (Jasanoff 2004: 14), maintaining political order "in the sense that it sustains particular structures of established power" (Jasanoff 2004: 31). In this light, it becomes possible to conceive European funding programs and the projects they sponsor less as providing support for the democratization of research processes and achievement of social transformation, and more as conduits for governmentality in a neoliberal policy environment. In such an environment, marginal partners in European TDR projects with relatively radical conceptualizations of sustainable development risk co-optation, or conferring legitimacy upon a system of science/policy governance with largely instrumental intentions.

\section{Conclusion}

Without a doubt, as the evolution of the European research policy framework and its concern with addressing so-called "grand societal challenges" (EC 2013) illustrates, "the science we use to apprehend political and economic impacts on the environment...is itself a product of both the political economy and the changing environment in which it is practised" (Peet et al. 2010: 39). However, the point of applying a political ecology lens to understanding the scalar dimensions and circulation of power within and around TDR projects is not to advocate in any way that CSOs or academics should avoid or abstain from collaborative research. Nor is it to suggest that large regional funding bodies should withdraw programmatic support for projects with 
transformative ambitions. On the contrary, all three projects indicate that the rewards of TDR heavily outweigh the discomforts, with the processes themselves often being recognized as more beneficial than actual project outputs or "deliverables." The point then is to ensure that potential collaborators embark on such endeavors fully prepared, able to anticipate the challenges that lie ahead and meet them head on. Similarly, there are lessons to be learned on the part of funding institutions that are both able and willing to embrace a genuinely transformative agenda.

\section{CSOs}

Within programs like SWAFS and increasingly within the initiatives designed to promote RRI, CSO partners stand to be increasingly sought after as partners, not only due to the expertise they bring to projects, but owing to the credibility their presence brings, as well as the eligibility for funding their participation confers upon projects. Given the circumstances described above in which CSOs frequently have less power than their academic counterparts, it is not surprising that non-academic partners, just like the members of social movements of which Jasper (2004: 5) writes, find themselves operating "within a complex set of cultural and institutional contexts that shape the players themselves, the options perceived, the choices made from among them, and the outcomes." Arguably, in TDR, CSOs are constantly engaged in politics, responding for example to "Engagement Dilemmas" (Jasper 2004: 13), deciding whether or not to subject their organizations to the risk of public misrepresentation, and related internal struggles over strategy. Similarly, "Extension Dilemmas" (Jasper 2004: 7), may also emerge, as working with a diversity of actors leads to divergence, disagreements, and ultimately the subordination of certain goals to those of more powerful partners. "The Dilemma of False Arenas" (Jasper 2004: 13), is also relevant here, as partners realize they have invested significant amounts of time/resources in a project that does not necessarily advance organizational goals. As all three projects have shown in different ways, in transdisciplinary research, CSOs are constantly required to make strategic choices that involve trade-offs of some sort or another, as they pursue wider objectives of social change (Jasper 2004: 10).

CSO partners (especially those new to TDR) are therefore advised to enter such projects fully conscious of the legitimacy their participation lends and of the pervasiveness of political dynamics in TDR, despite the egalitarian intentions of partners and the sympathies of collaborators. CSO partners should also be prepared to engage as fully as possible in the project inception period, ensuring expectations, roles and capacities are as clear as possible throughout the project cycle, and producing detailed budgets that account for CSO needs in terms of communication (including translation), both with research partners and their wider constituents. Finally, CSO partners should insist, from the conception stage, on the financing and building-in of regular opportunities for open and frank discussions with their academic counterparts about how cooperative processes are working (or not), along with other issues of mutual concern. These measures are indeed vital if CSOs are to ensure they are able to shape projects in ways that benefit their own organizational goals directly, rather than as a by-product of an otherwise primarily academic undertaking or science/policy related trust-building exercise.

\section{Academics}

Academic partners for their part are advised not to underestimate the significance of the cultural/institutional differences between themselves and CSO stakeholders. Such an awareness necessarily implies that academics appreciate the crucial nature of the project inception stage, especially if integrationrelated politics are to be minimized. Inception planning on the part of academics should also consider that CSOs, whether they are research-oriented or not, are likely to have fewer resources to contribute to this vital phase (as well as to administrative issues related to the EC), and may need extra support to contribute fully. In addition, researchers should be prepared to allocate resources adequate to meet the needs of effective communication in TDR projects. This means planning not only for opportunities to discuss methodological issues, or to plan dissemination activities, but for deliberate, regular opportunities in which cooperative research processes themselves can be jointly discussed. Project coordinators should anticipate the need for less formal opportunities for interaction, in which ideas can be exchanged, areas of synergy can be identified, and interactions in general can contribute to the generation and maintenance of trust among partners. 
Finally, academics should also be prepared to take a more reflexive approach to their work in TDR not just to see CSOs as valuable sources of lay knowledge, or a means to some end of increasing research relevance, but to be open to lessons learned about processes along the way, as well as unknown "ends." These lessons moreover should not only be documented for project reports, but published as part of methodological accounts of the research that is co-produced in projects. Such work would go a long way to amplify the importance of cooperative processes, sharing lessons on the opportunities and challenges encountered along the way, so that other aspiring transdisciplinary researchers might benefit from the more "intangible" benefits of knowledge co-production.

\section{Research policymakers}

As Wiek et al. (2012: 22) have argued, if sustainability science is to realize its true transformative value, "a significant shift of individual research agendas and institutions, beyond programmatic claims and calls", is necessary. So far, such shifts have yet to occur. DG RTD has so far attempted to make its research program more amenable to TDR by publishing calls for the investigation, for example, of "alternative ways" of evaluating the work of researchers, projects, and scientific publications. The Directorate has also called for the conceptualization of new incentive schemes that complement traditional research incentive structures (20101.3.3-1). ${ }^{4}$ Also published have been calls for facilitating increased CSO access to the SWAFS work program by building capacities of National Contact Points (NCPs). However, more fundamental demands for structural changes to open up opportunities for agenda-setting, and to enable CSOs to identify topics of concern to them and the wider publics they represent, have been systematically disregarded.

In such a light, DG RTD seems to have shifted away from its earlier trajectory aimed at inculcating more reflexive practices in research and research policy making, toward a "toolkit" approach to developing and promoting RRI, which seeks merely to "manage" processes rather than learn from them. Indeed the apolitical approach to RRI that has been adopted by the European Commission has not escaped criticism, with observers noting a largely instrumental approach, a "procedural" orientation, and a failure to consider "questions of power, ends, and authority that play out in, and through, RI processes" (van Oudheusden 2014: 69). They argue the hegemony of instrumentalism within powerful institutions of science/policy governance is rooted in the prevailing bias within science, and by extension within science/policy interaction (O'Connor 1999) toward positivism (Söderbaum 2007), which privileges a view of social reality as a set of measurable data or facts to be collected and analyzed by scientifically trained experts. This approach they argue, necessitates institutional arrangements that preclude more radical and necessary institutional transformations toward sustainability (Norgaard 2008; O'Connor 1999), ultimately producing strategies for public engagement in science that tend more toward paternalism than transformation.

Thus, if DG RTD is to pursue its stated objective of harnessing the transformative potential of TDR with sincerity, officials and representatives must themselves be prepared to drive the necessary changes at Commission level. As a starting point, Directorate staff should begin to acknowledge and address the fact that the political dynamics present in TDR projects are exacerbated by structural conditions, responding with more adequately designed funding instruments and conditions able to minimize tensions in projects. Measures could be taken for instance to a provide seed funding for the preparation of large complex projects involving a broad range of (and especially CSO) stakeholders, to increase budgetary allowances, and to support activities related to proposal development, project administration, translation of outputs into the languages of beneficiaries, and communication more broadly, not only amongst consortium members but also between projects and research policy makers. To this end, DG RTD ought to develop a mechanism along the lines of RBSG-TDR (resuscitating and transforming the former RBSG-CSOs scheme), which could be informed by existing accumulated knowledge gained from the many "harvesting" sessions already run with experienced TDR practitioners and beneficiaries of EU funding. Perhaps most crucially, however, DG RTD needs to reopen what has become a significantly narrowed scope for CSO engagement in both research and research policy agenda setting under Horizon 2020 and its narrow and techno-centric approach to defining "societal challenges."

\footnotetext{
${ }^{4} \underline{\text { https://ec.europa.eu/research/participants/portal/doc/call/fp7/fp7-science-in-society-2010-1/15195-s ct } 201001 \text { en.pdf }}$
} 
More substantially, however, proponents of Responsible Research and Innovation (RRI) within the Commission and DG RTD must appreciate that the concept of responsible innovation is normative, with transformative ambitions that require more than an instrumental application of reflexivity. This point has not been lost on Chilvers and Kearnes (2016: 16) who call upon powerful and incumbent scientific, political and economic institutions to treat reflexivity not as a separate procedural add-on, but instead to pay attention to "framing effects, exclusions, contingencies and uncertainties as a characteristic feature of all participatory collectives." In practice this will necessitate a willingness on the part of European policymakers to discuss the fundamentally political nature of TDR and show a willingness to scrutinize the EC's own "institutional uptake" of RRI. Not to do so, as they warn, ultimately risks "trivializing and undermining" the very policy changes RRI advocates seek to instigate" (van Oudheusden 2014: 81).

\section{References}

Aniekwe, C.C., R. Hayman, A. Mdee, J. Akuni, P. Lall, and D. Stevens. 2012. Academic-NGO collaboration in international development research: a reflection on the issues. Development Studies Association (UK and Ireland) and the International NGO Training and Research Centre (INTRAC), University of Bradford and World Vision UK.

Avc1, D., F. Adaman, and B. Özkaynak. 2010. Valuation languages in environmental conflicts: how stakeholders oppose or support gold mining at Mount Ida, Turkey. Ecological Economics 70(2): 228238.

Beck, U. 1999. World risk society. Cambridge: Polity Press.

Beck, U., S. Lash and B. Wynne. 1992. Risk society: towards a new modernity. London: Sage.

Borchelt, R.E., L.T. Friedmann, and E. Holland. 2010. Managing the trust portfolio: science public relations and social responsibility. In G. Kennedy and G. Overholser (eds.). Science and the media. Cambridge, MA: American Academy of Arts and Sciences. Pp. 64-93.

Burchel, G., C. Gordon and P. Miller. 1991. The Foucault effect: studies in governmentality. Chicago: University of Chicago Press.

Callon, M. and J. Law. 1982. On interests and their transformation: enrolment and counter-enrolment. Social Studies of Science 12(4): 615-625.

Callon, M. 1986. The sociology of an actor-network: the case of the electric vehicle. In M. Callon, J. Law and A. Rip (eds.). Mapping the dynamics of science and technology. London: Palgrave Macmillan. Pp. 1934.

Casas-Cortés, M.I., M. Osterweil and D.E. Powell. 2008. Blurring boundaries: recognizing knowledgepractices in the study of social movements. Anthropological Quarterly (81)1: 17-58.

Chilvers, J. and M. Kearnes (eds.). 2016. Remaking participation: science, environment and emergent publics. London: Routledge.

Clapp, J. 2014. Second EJOLT evaluation report, Barcelona. Available at http://www.ejolt.org/wordpress/wpcontent/uploads/2014/05/EJOLT-Evaluation-May-2014-.pdf [Accessed 15/09/2019].

CREPE. 2009. Work Package 3: Water scarcity and its virtual export from Spain to the UK. Deliverable D3.1: Workshop report. Available at https://fnca.eu/images/documentos/proy\%20CREPE/proy-crepe-201009-(2009)-sintextensa.pdf [Accessed Sept 15 2019].

CREPE. 2010a. Annex I - Revised description of work. London: Open University.

CREPE. 2010b Work Package 3: Water scarcity and its virtual export from Spain to the UK. Available at: http://www.crepeweb.net/wp-content/uploads/2010/12/crepe-wp3-final-report.pdf $\quad$ [Accessed $10 / 04 / 2019]$.

CREPE. 2010c Work Package 8: Cooperative research processes in CREPE: final report. Available at: http://www.crepeweb.net/wp-content/uploads/2010/12/crepe-wp8-final-report.pdf $\quad$ [Accessed 29/08/2016]. 
CREPE. 2011 Agricultural innovation: sustaining what agriculture? For what European bio-economy? Final project report. Available at: https://www.tni.org/files/download/CREPE_Final_Report.pdf Accessed 15/09/2019].

Dutta, U. 2014. Critical ethnography. In J. Mills and M. Birks. (eds.). Qualitative methodology: a practical guide. London: Sage. Pp. 89-106.

Edelman, M. 2009. Synergies and tensions between rural social movements and professional researchers. Journal of Peasant Studies 36(1): 245-265.

EJOLT. 2010. Annex I - Description of work. Barcelona: Autonomous University of Barcelona.

EJOLT 2014. Final report summary. Available at https://cordis.europa.eu/project/rcn/98856/reporting/en [Accessed 10/04/2019]

Engage 2020. Current praxis of policies and activities. Available at http://engage2020.eu/media/D3.1-CurrentPraxis-of-Policies-and-Activities.pdf [Accessed 10/04/2019].

European Commission, nd. The Common Fisheries Policy (CFP), Managing fisheries. Available at http://ec.europa.eu/fisheries/cfp/fishing_rules/discards/index_en.htm [Accessed 10/04/2019].

European Commission. 2006. From science and society to science in society: towards a framework for 'cooperative research'. Available at https://publications.europa.eu/en/publication-detail//publication/4bd7721c-677f-457d-8ba3-9186f64c1823 [Accessed 14/11/2017].

European Commission. 2009. FP7 Capacities Work Programme: Science in Society C(2009)5905 of 29 July 2009.

European Commission. 2010. How ways of doing research are evolving in order to address societal challenges. Available at https://ec.europa.eu/research/science-society/document_library/pdf_06/nwdrreport_en.pdf [Accessed 29/08/2016].

European Commission. 2012. Monitoring policy and research activities on science in society in Europe (MASIS). Final synthesis report. Available at https://ec.europa.eu/research/sciencesociety/document_library/pdf_06/monitoring-policy-research-activities-on-sis_en.pdf $\quad$ (accessed 15/09/2019].

European Commission. 2012b. How to evolve the MML - workshop report. Brussels: European Commission.

European Commission. 2013. Horizon 2020 work programme 2014-2015 - science with and for society. Brussels. DG RTD Available at https://ec.europa.eu/research/participants/data/ref/h2020/wp/2014_2015/main/h2020-wp1415swfs en.pdf [Accessed 29/08/2016].

Ferretti, M.P. and V. Pavone. 2009. What do civil society organizations expect from participation in science? Lessons from Germany and Spain on the issue of GMOs. Science and Public Policy 36(4): 287-299.

Funtowicz, S. and J. Ravetz. 2003. Post-normal science. In Online encyclopedia of ecological economics. Available from http://isecoeco.org/pdf/pstnormsc.pdf [Accessed on Sept 15 2019].

Funtowicz, S. and J. Ravetz. 1993. The worth of a songbird: ecological economics, as a post-normal science. Ecological Economics 10: 197-207.

Funtowicz, S. and J. Ravetz. 1991. A new scientific methodology for global environmental issues. In R. Costanza (ed.). Ecological economics: the science and management of sustainability. New York: Columbia University Press. Pp. 137-152.

Gall, Eric, G. Millot and C. Neubauer. 2009. Participation of Civil Society Organizations in research, science, technology and civil society science, technology and civil society (STACS). Downloaded Sept 162019 from https://sciencescitoyennes.org/wpcontent/uploads/2011/09/STACS_ParticipationInResearch.pdf

GAP2, nd, a. Executive summary 18 month progress report. Available at http://gap2.eu/gap2wordpress/wpcontent/uploads/2014/12/D6.1.1-GAP2-Progress-report_18-months.pdf [Accessed 15/09/2019].

GAP2. Nd, b. Norway - coastal cod management. Available at http://gap2.eu/gap2wordpress/wpcontent/uploads/2015/03/Norway-CS5.pdf [Accessed 15/09/2019]. 
GAP2. 2011. First Meeting for Norway's fishermen \& scientists. Available at http://gap2.eu/casestudies/norwegian-coastal-cod/norway-scientists-and-fishers-meet/ [Accessed 15/09/2019].

GAP2. 2013. 24 months on: progress for Norway case study. Available at http://gap2.eu/casestudies/norwegian-coastal-cod/24-months-on-progress-for-norway-case-study/ [Accessed 15/09/2019].

GAP2. 2014. Annex 1 - "Description of Work". Lowestoft, UK: Centre for Environment Fisheries and Aquaculture Science.

Gibbons, M., C. Limoges, H. Nowotny, S. Schwartzman, P. Scott, and M. Trow. 1994. The new production of knowledge: the dynamics of science and research in contemporary societies. London: Sage.

Giddens, A. 1995. Beyond Left and Right. Cambridge: Polity Press.

Goeminne, G. and E. Paredis. 2008. The concept of ecological debt: an environmental justice approach to sustainability, calling for radical transitions in industrialised countries. In S. Vemuri (ed.) Connected accountabilities: environmental justice and global citizenship. Oxford: Interdisciplinary Press. Pp. 3671.

Görg, C., J. Spangenberg, V. Tekken, B. Burkhard, D. Thanh Truong, M. Escalada, K. Luen Heong, G. Arida, L.V. Marquez, J. Victor Bustamante and H. Van Chien. 2014. Engaging local knowledge in biodiversity research: experiences from large inter-and transdisciplinary projects. Interdisciplinary Science Reviews 39(4): 323-341.

Greyl, L., H. Healy, E. Leonardi and L. Temper. 2012. Stop that train! Ideological conflict and the TAV. Economics and Policy of Energy and the Environment 8: 219-244.

Hadorn, G.H., S. Biber-Klemm, W. Grossenbacher-Mansuy, H. Hoffmann-Riem, D. Joye, C. Pohl, U. Wiesmann and E. Zemp (eds.). 2008. Handbook of transdisciplinary research. Zurich: Springer.

Hadorn, G.H., D. Bradley, C. Pohl, S. Rist and U. Wiesmann. 2006. Implications of transdisciplinarity for sustainability research. Ecological Economics 60(1): 119-128.

Hajer, M.A. 1995. The politics of environmental discourse: ecological modernization and the policy process. Oxford: Clarendon Press.

Irwin, A. 2006. The politics of talk: coming to terms with the 'new' scientific governance. Social Studies of Science 36(2): 299-320.

Irwin, A. 2008. STS perspectives on scientific governance. In U. Felt, R. Fouche, C. Miler and L. Smith-Doer (eds.). The handbook of science and technology studies ( $4^{\text {th }}$ ed.). Cambridge: MIT Press. Pp. 583-608.

Jahn, T., M. Bergmann and F. Keil. 2012. Transdisciplinarity: between mainstreaming and marginalization. Ecological Economics 79: 1-10.

Jasanoff, S. 1996. Beyond epistemology: relativism and engagement in the politics of science. Social Studies of Science 26(2): 393-418.

Jasanoff, S. (ed.). 2004. States of knowledge: the co-production of science and the social order. London: Routledge.

Jasper, J.M. 2004. A strategic approach to collective action. Mobilisation 9(1): 1-16.

Kuhn, R., G. Mbungu, E. Anderson, B. Chonkova, Z. Damianova, H. Davis, S. Dencker, M.L. Jørgensen, V. Kozarev, G. Larsen, H. Mulder and S. Pfersdorf. Engage 2020: Report on current praxis of policies and activities supporting societal engagement in research and innovation. Available from http://engage2020.eu/media/D3.1-Current-Praxis-of-Policies-and-Activities.pdf [Accessed April 10 2019].

Lang, D.J., A. Wiek, M. Bergmann, M. Stauffacher, P. Martens, P. Moll, M. Swilling and C.J. Thomas. 2012. Transdisciplinary research in sustainability science: practice, principles, and challenges. Sustainability Science 7(1): 25-43.

Latour, B. 1987. Science in action: how to follow scientists and engineers through society. Cambridge: Harvard University Press.

Levidow, L. and S. Oreszczyn. 2012. Challenging unsustainable development through research cooperation. Local Environment 17(1): 35-56. 
Maasen, S. and O. Lieven. 2006. Transdisciplinarity: a new mode of governing science? Science and Public Policy 33(6): 399-410.

Madison, D.S. 2005. Critical ethnography: method. ethics, and performance. Thousand Oaks.

Mackinson, S. 2013. Bridging the gap between science, stakeholders and policy makers. Presentation to DG Research \& Innovation, 26th September 2013.

Martinez-Alier, J. 2002. Mining conflicts, environmental justice and valuation. In Agyeman, J., R.D. Bullard and B. Evans (eds.). Just sustainabilities: development in an unequal world. Cambridge: MIT Press. Pp. 153-170.

Martinez-Alier, J. 2009. Social metabolism, ecological distribution conflicts, and languages of valuation. Capitalism Nature Socialism 20(1): 58-87.

Martinez-Alier, J., I. Anguelovski, P. Bond, D. Del Bene, F. Demaria, J.F. Gerber, L. Greyl, W. Haas, H. Healy, V. Marín-Burgos, G. Ojo, M. Porto, L. Rijnhout, B. Rodríguez-Labajos, J. Spangenberg, L. Temper, R. Warlenius and I. Yánez. 2014. Between activism and science: grassroots concepts for sustainability coined by Environmental Justice Organizations. Journal of Political Ecology 21(1): 19-60.

Meynen, N. and L. Sébastien. 2013. Environmental Justice and Ecological Debt in Belgium: the UMICORE case. In H. Healy, J. Martinez-Alier, M. Walter and J.F. Gerber (eds.). Ecological economics from the ground up. London: Routledge. Pp. 450-484.

Mol, A.P. 1995. The refinement of production. ecological modernization theory and the chemical industry. Utrecht: Van Arkel.

Mosse, D. 2005. Cultivating development: an ethnography of policy and practice. London: Pluto Press.

Murphy, J. and A. Gouldson. 2000. Environmental policy and industrial innovation: integrating environment and economy through ecological modernisation. Geoforum 31(1): 33-44.

Norgaard, R.B. 2008. The implications of interdisciplinary scientific assessments for environmental governance. In J. Ranganathan, M. Munasinghe and F. Irwin (eds.) Policies for sustainable governance of global ecosystem services. London: Edward Elgar. Pp. 235-253.

Nowotny, H. 2003. Democratising expertise and socially robust knowledge. Science and Public Policy 30(3): 151-156.

O'Connor, M. 1999. Dialogue and debate in a post-normal practice of science: a reflexion. Futures 31(7): 671687.

Peet, R., P. Robbins, and M.J. Watts (eds.). 2010. Global political ecology. London: Routledge.

Pohl, C. 2008. From science to policy through transdisciplinary research. Environmental Science and Policy 11(1): 46-53.

Pohl, C. and G.H. Hadorn. 2008. Methodological challenges of transdisciplinary research. Natures Sciences Sociétés 16(2): 111-121.

Popa, F., M. Guillermin and T. Dedeurwaerdere. 2015. A pragmatist approach to transdisciplinarity in sustainability research: from complex systems theory to reflexive science. Futures 65: 45-56.

Roper, L. 2002. Achieving successful academic-practitioner research collaborations. Development in Practice 12(3-4): 338-345.

Rose, N. and P. Miller. 1992. Political power beyond the state: problematics of government. British Journal of Sociology 61(s1): 173-205.

Russell, A.W., F. Wickson and A.L. Carew. 2008. Transdisciplinarity: context, contradictions and capacity. Futures 40(5): 460-472.

Siebenhüner, B. 2008. Learning in international organizations in global environmental governance. Global Environmental Politics 8(4): 92-116.

Spaapen, J. and L. van Drooge. 2011. Introducing 'productive interactions' in social impact assessment. Research Evaluation 20(3): 211-218.

Spangenberg, J.H. 2011. Sustainability science: a review, an analysis and some empirical lessons. Environmental Conservation 38(3): 275-287. 
Stevens, D., R. Hayman and A. Mdee. 2013. Cracking collaboration between NGOs and academics in development research. Development in Practice 23(8): 1071-1077.

Söderbaum, P. 2007. Science, ideology and development: is there a 'Sustainability Economics?'. Post-Autistic Economics Review 43: 24-41.

Sugiyama, M., S. Asayama, T. Kosugi, A.Ishii, S. Emori, J. Adachi, K. Akimoto, M. Fujiwara, T. Hasegawa, Y. Hibi and K. Hirata. 2017. Transdisciplinary co-design of scientific research agendas: 40 research questions for socially relevant climate engineering research. Sustainability Science 12(1): 31-44.

van Oudheusden, M. 2014. Where are the politics in responsible innovation? European governance, technology assessments, and beyond. Journal of Responsible Innovation 1(1): 67-86.

Wiek, A., B. Ness, P. Schweizer-Ries, F.S. Brand and F. Farioli. 2012. From complex systems analysis to transformational change: a comparative appraisal of sustainability science projects. Sustainability Science 7(1): 5-24.

World Commission on Environment and Development. 1987. Our common future. Oxford: Oxford University Press.

Wynne, B. 2006. Public engagement as a means of restoring public trust in science-hitting the notes, but missing the music? Public Health Genomics 9(3): 211-220. 